\title{
19. Yüzyıl Türk Sivil Mimarisinde Duvar Resmi Estetiği ve İstanbul Teması
}

\author{
Deniz DEMIRARSLAN ${ }^{1 *}$
}

\section{Öz}

İstanbul kentsel tarihi 3 bin yıl öncesine dayanan, Avrupa ile Asya kıtalarının birleştiği noktada bulunan bir şehirdir. Şehir çağlar boyunca farklı uygarlık ve kültürlere ev sahipliği yapmış, yüzyıllar boyu çeşitli din, dil ve ırktan insanların bir arada yaşadığı kozmopolit ve metropolit yapısını korumuş ve tarihsel süreçte eşsiz bir kültürel mozaik halini almıştır. Tarih boyunca yaşamın her alanında olduğu gibi özellikle kültür ve sanat konularında da merkez olmuş ve bu merkezde oluşan tüm gelişmeler dünyayı da etkisi altına almıştır. İstanbul şehri özellikle resim sanatına da konu olmuş; insanların bu kente olan hayranlıkları ve özlemleri resim sanatı ile dile getirilmeye çalışıımıştır. Bu durum öncelikle hem Avrupa resim sanatında hem de Türk resim sanatında daha sonra da iç mekân dekorasyonlarında yeniliklere yol açmış ve gerek Avrupa'da gerekse de Osmanlı İmparatorluğu sınırları içerisinde günlük yaşamda değişikliklere neden olmuştur. Osmanlının Batılılaşma döneminde ortaya çıkan ve İstanbul'u konu alan bu yeni resim anlayışının ilk görüldüğü yer ise Türk sivil mimarisinin estetik yönünden zenginleşmesinde önemli yeri bulunan "kalem işi" olarak isimlendirilen duvar resimleridir. Bu nedenle bu resimlerin incelenmesi ile Osmanlı İmparatorluğu'nda Batılılaşmanın ortaya çıkışı ve sonuçlarını görmek aynı zamanda da bu süreçte Avrupa'nın Osmanlı- Türk kültüründen nasıl etkilendiğini anlamak mümkündür. Günümüze dek bu konuya ilişkin çok az sayıda çalışmanın yapılmış olması ve resim sanatı ile mimarinin ilgisinin kurularak estetik yönünün yanında sosyo-kültürel açıdan da konuya yaklaşılması çalışmanın önemini daha da artırmaktadır.

Anahtar Kelimeler: İç Mimari, Duvar resmi, Türk resmi, Oryantalizm, Batılılaşma, İstanbul.

\section{Wall Painting Aesthetics and Istanbul Theme in The 19th Century Turkish Civilian Architecture}

\begin{abstract}
Istanbul is the city of which urban history dates to 3000 years back and located in the meeting point of continents Europe and Asia. Throughout ages, the city has hosted an abundance of civilizations and cultures, preserved the cosmopolitan and metropolitan structure that enabled the coexistence of various religions, languages and races and within historical process, it has turned into a unique cultural mosaic. During the course of history, just like each and every sphere of life, it has become a center of culture and art in particular; besides all the developments emerging in this center have captured the world outside as well. City of Istanbul has been the topic of painting specifically; the admiration and longing people nourished for this city have been attempted to portray through art of painting. This event introduced changes initially in European painting then Turkish painting and interior space decorations. Additionally, within European as well as Ottoman Empire borders, it has introduced alterations in daily life. The first area that the new painting approach having emerged during Westernizing process of Ottomans and focused on Istanbul is wall painting that has a noteworthy place in the aesthetical enrichment of Turkish civilian architecture. For that reason, by analyzing these paintings, it is possible to view the emergence and consequences of Westernization in Ottoman Empire and besides understand the way Europe was affected from Ottoman-Turkish culture during this process. The fact that so far there has been limited numbers of researches on this topic elevates the vitality of this study which attempts to establish a connection between painting and architecture and analyzes its aesthetical as well as socio-cultural aspect.
\end{abstract}

Keywords: Interior architecture, wall painting, Turkish art of painting, Orientalism, Westernization, Istanbul.

\footnotetext{
${ }^{1}$ Doç. Dr., Kocaeli Üniversitesi, Mimarlık ve Tasarım Fakültesi, İç Mimarlık Bölümü, denizdemirarslan@gmail.com *ilgili yazar / Corresponding author: Deniz DEMIRARSLAN, denizdemirarslan@gmail.com Gönderim Tarihi: 08.11 .2016

Kabul Tarihi: 20.11.2016
} 


\section{GíRiş}

2010 yılı Avrupa kültür başkenti olarak ilan edilen İstanbul, tarihte dünyanın en önemli başkentlerinden birisi olmuştur. Eşsiz coğrafi ve kültürel yapısı hâlihazırda tüm dünyayı etkilemiş ve halen de etkilemeye devam etmektedir. Başta Latin, Bizans ve Osmanlı İmparatorlukları olmak üzere çeşitli uygarlıkları barındırmış olan kent bu uygarlıkların izlerini birbirinden farklı dönemlerde yapılmış mimari örneklerde taşımaktadır. Ancak, 19. yüzyılda ivme kazanan ve Osmanlı toplumunu yaşamın her alanında tamamıyla değiştiren Batılılaşma hareketinin izleri, mimari örneklerde olduğu kadar sanatsal öğelerde de daha belirgin unsurlarla göze çarpmaktadır. Bu unsurların içinde Osmanlı'nın Batılılaşması ile birlikte paralel bir gelişim gösteren ve Türk sivil mimarisinin önemli süsleme teknikleri arasında yer alan "kalem işi" olarak isimlendirilen duvar resmi tekniği göze çarpmaktadır. Bu duvar resimleri içinde en fazla ilgi çekenler İstanbul temalı olanlardır.

\section{1.Çalışmanın Amacı}

Gürçağlar'ın da eserinde (2005: 234) belirttiği gibi; özellikle 18. yüzyılın ortalarından sonra Türk sivil mimarisindeki örnekleri dikkat çekici olan perspektifli duvar manzara resimlerinin saray, köşk, konak, kasır gibi yüksek tabakaya ait konutlarda yaygınlaşmasının mimari mekân ve süsleme yönünden sanatsal nedenleri olduğu gibi sosyo-kültürel ve ekonomik nedenleri de bulunmaktadır. Bu resimler hem Türk sivil mimarisindeki iç mekân dekorasyonunun gelişimini yansıtan hem de toplumun modernleşme sürecinde geçirdiği aşamaların görülebildiği eşsiz örnekler olması açısından önemlidir. İstanbul temalı bu duvar resimleri ile ulaşılmak istenen hedef İstanbul özleminin ve hayranlığının dile getirilmesinden öte, esasen Avrupa kültürüne olan hayranlığın ve özlemin dile getirilmesi anlamını taşımaktadır. Bu duvar resimleri sadece bir mekânın iç dekorasyonundaki değişiminin değil; aslında bir toplumun sosyokültürel anlamdaki değişiminin en önemli kanıtıdır. Bu nedenle bu çalışmanın ana amacı Batılılaşma döneminde Türk sivil mimarisinin önemli süsleme unsurlarından biri olan duvar resmi uygulamasında tema olarak İstanbul'un işlenmesinin ana nedenlerini araştırmak ve bu uygulamanın Türk resim sanatı ile konut iç dekorasyonu ve toplum üzerindeki etkilerini örnekler üzerinde inceleyerek sonuçlara varmaktır.

\section{2. Çalışmanın Yöntemi}

Çalışma hazırlık, alan araştırması ve sonuçların çıkarılması olarak üç kısımdan oluşmaktadır. Çalışmanın hazırık safhasında özellikle Osmanlı İmparatorluğu'nda Batılılaşma dönemi, Türk resim sanatı, Türk sivil mimarisi ve duvar resmi konularına ilişkin önemli yazılı kaynaklar üzerinde incelemeler yapılmıştır. Çalışmanın araştırma safhasında ise bu duvar resimlerinin bulunduğu örnekler üzerindeki araştırmalar için yine öncelikle yazılı ve görsel kaynaklardan yararlanılmış ve bazı örnekler yerinde incelenmiştir.

Bu tür duvar resimlerinin en önemli örnekleri 18. yüzyılın ilk yarısı Lale Devri'nde (1718-1730) Topkapı Sarayı'nda yapılmıştır. 19. yüzyılda ise Osmanlı'nın Batılılaşan yönünü vurgulamak için inşa ettirilen Dolmabahçe Sarayı'nın iç mekânlarında ve yine aynı yüzyılda inşa edilen geleneksel konutlarda görülmektedir. Bu amaçla Topkapı ve Dolmabahçe Sarayları ile özellikle geleneksel Türk evlerinin en önemli örneklerini barındıran Kuzey Batı Anadolu'daki Kocaeli, Safranbolu yöresi Yörükköy ve Bursa Yenişehir'de yerinde incelemeler yapılarak söz konusu örnekler fotoğraflar ile belgelenmiş ve sunulmuştur. Anadolu ve Balkanlarda yer alan diğer örnekler için ise yazılı ve görsel belgelerden yararlanılmıştır. Çalışmanın sonuç kısmında bu incelenen 
örnekler ile hazırlık aşamasında taranan belgelerden elde edilen bilgilerin bir analizi yapılarak konunun estetik yönden ele alınmasının yanı sıra Osmanlı- Türk toplumu ve Avrupa üzerindeki etkileri ortaya konulmuştur.

Bu duvar resimlerini örneklerle incelemeye geçmeden önce dönemin sosyo-kültürel özelliklerinin değişimine ve yaşamın her alanında yeniliklere neden olan Osmanlı'da Batılılaşma hareketi konusuna değinmek faydalı olacaktır. Ayrıca, Türk sivil mimarisinde süsleme tekniklerinden kısaca söz etmek ve bu tekniklerin içinde duvar resminin Batılılaşma hareketi ile gelişimine değinmek konunun daha iyi anlaşılabilmesi açısından gerekmektedir.

\section{Osmanlı İmparatorluğu’nda Batılılaşma dönemi ve etkileri}

Tüm dünyada olduğu gibi Osmanlı İmparatorluğu'nda da Batılılaşma ya da diğer ismiyle Modernleşme hareketi tüm yönleriyle 19. yüzyılda yoğun bir şekilde yaşanmış ve toplumun tüm tabakalarını zamanla etkileyerek askeri, sosyal, siyasi, sanatsal, hukuksal, ekonomik ve yaşamsal birçok yönden değişimlere neden olmuştur. Daha 16. ve 17. yüzyıllarda görülmeye başlanan Osmanlı yaşamındaki Batı etkisi Osmanlı toplumunun yeniliklere çok da açık olmaması nedeniyle tam anlamıyla 19. yüzyılda etkisini gösterebilmiştir. Ancak, 18. yüzyıl Osmanlı ve Batı toplumu arasındaki ilişkilerin yeni bir boyut kazandığı dönemdir. Bu dönemde Osmanlı'nın Avrupa kentlerine elçiler yollaması gelişen ilişkilerin bir göstergesidir. Özellikle Avrupa ülkeleri ile olan yakın ilişkiler sonucu öncelikle Avrupa'nın görgü kuralları, giyim tarzı, edebiyatı ile birlikte konut kullanım alışkanlıkları ve özellikle de konut iç dekorasyonu ile ilgili yenilikler yaygınlık kazanarak önce İstanbul'da daha sonra İmparatorluğun diğer önemli kentlerinde görülmeye başlanmıştır. Bu değişim ve yeniliklerin arasında konutlarda Batı tarzı mobilya ve eşyaların kullanılmaya başlanması, geleneksel süsleme yöntemlerinin yerini Batı tarzı süsleme tekniklerine bırakması, konutların değişen yaşam tarzına uygun bir şekilde planlanması ve Batı tarzı konut plan tipinin benimsenmesi yer almaktadır (Demirarslan, 2007: 603).

Bu dönemde Batının Doğuya ve Osmanlı'ya yönelik ilgisi de dikkat çekicidir. Arlı'nın eserinde (2000: 29) değindiği üzere Fransa'da 16. ve 18. yüzyıllar arası Türk sanatı ve kültüründen etkilenerek oryantalist bir akım olarak gelişen "Turqueri" modası, Batının Doğu ilgisini açıkça ortaya koymaktadır. Resim, edebiyat ve moda gibi alanlarda bu akım etkisini göstermiştir. Örneğin; Rembrandt ve Rubens gibi ünlü ressamlar Doğu ve Türk imgelerini resimlerinde konu almıştır. Binbirgece Masalları Paris'te Antoine Galland'ın çevirisi ile yayınlanmış, 1782'de Mozart "Saraydan Kız Kaçırma” operasını yazmıştır. Fransız aristokratlarının Osmanlı kıyafetleri içerisinde çok sayıda resim yaptırdıkları da görülmektedir. 18. yüzyılda tarih ve klasik döneme olan ilginin canlanması Batılı aydınların gözlerini Doğuya çevirmelerine neden olmuştur. Çok sayıda Batılı elçi ve gezgin içlerindeki macera duygusunun da etkisiyle Osmanlı topraklarına özellikle de İstanbul'a gelerek incelemelerde bulunmuşlardır. Bu gezilere çoğu zaman Batılı ressamlar da eşlik etmiştir. Antoine- Ignace Melling, Fausto Zonaro, Leonardo Mango, Salvatore Valeri, Jean Leon Geromé, Jean Baptiste Hilaire gibi ressamların çalışmaları sayesinde bu gezilerin sonucunda İstanbul'u konu alan albümler hazırlanmıştır (Arlı, 2000: 64). Örneğin, Hilaire'in İstanbul evlerini resmettiği desenleri 1787 yılında Paris'te basılan "Tableau Général de l'Empire Ottoman" isimli kitapta yer almıştır. Şekil-1'de Hilaire'in bu sözü edilen İstanbul gezisi sırasında yapmış olduğu manzara çalışmaları görülmektedir. 

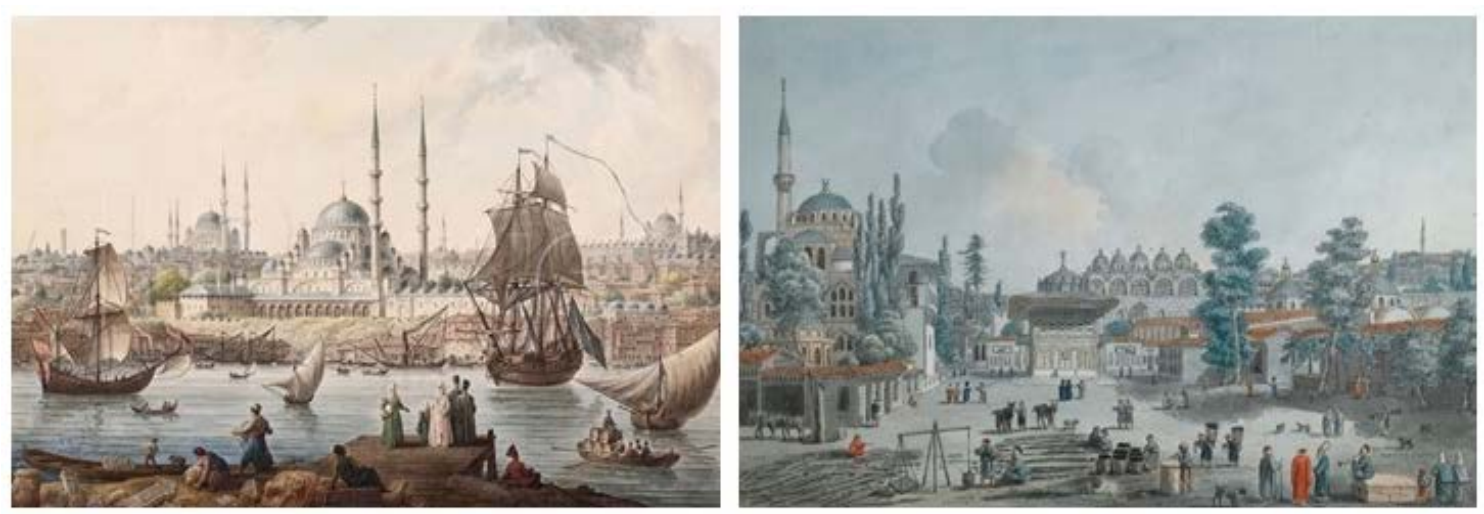

Şekil 1. Ressam Jean Baptiste Hilaire'in İstanbul ve Tophane konulu yağlıboya tabloları (URL1).

Önceleri bir tür egzotizm olarak resme yansıyan bu Doğu ilgisi zamanla ve özellikle de 19. yüzyılın ortalarında bir oryantalizm hareketi olarak dışa vurulmuştur. "Turqueri" modası toplumları sadece estetik açıdan etkilememiştir. Yine "Turqueri" ve "Oryantalizm" konusunda araştırmalar yapan Arlı'nın eserinde (2000: 13) bu modanın yayılması sonucunda 12. yüzyıldan beri Avrupa haritalarında Anadolu olarak isimlendirilen topraklara Avrupalılar tarafından "Türkiye" adının verilmeye başlanmasının olayın politik ve siyasi yönüne de işaret ettiği vurgulanmaktadır.

Batıda Osmanlı hayranlığı sürmekte iken; 19. yüzyılda Osmanlı'nın başkenti İstanbul'dan başlayarak zamanla diğer kentlere doğru yayılan kültürel ve sosyal yaşamdaki Batı tarzı değişim ise özellikle Anadolu ve Balkanlardaki diğer kentlerde yaşayan insanlarda da İstanbul hayranlığı uyandırmıştır. Çünkü o dönemde İstanbul geleneksellikten uzaklaşmanın, Batılı olmanın, çağdaşlaşmanın merkezi olarak her tabakadan insanın ilgisini çekmiştir. Bu ilgi ve hayranlık Türk sivil mimarisinin iç mekânlarındaki süslemelerde özellikle de duvar resmi ile dile getirilmiştir.

\section{Türk sivil mimarisinde süsleme}

Türk sivil mimarisi saraylar, köşkler, yalılar, geleneksel konutlar, çeşmeler ve sebiller gibi yapılardan oluşmaktadır. Özellikle iç mekânda kullanılan süsleme teknikleri bu mimarinin önemli estetik unsurlarıdır. Türk sivil mimarisinde süsleme sanatları İslam dininin Türkler tarafından kabulünden önceki dönem, İslam'ın kabulünden sonraki dönem ve Batılılaşma süreci olarak görülmektedir. İslam'ın kabulünden itibaren süslemelerde motiflerin belirlenmesi ve kullanılmasında İslami kurallar etkili olmuştur. Selçuklu, Beylikler Dönemi ve Osmanlı İmparatorluğu dönemlerinde kullanılan teknik ve malzemelerde farklılıklar gözlense bile ilkelerin aynı olduğu görülmektedir. Mimaride kullanılan süsleme teknikleri arasında taş, çini, ağaç süslemecilikleri ve "kalem işi" olarak isimlendirilen duvar resmi süslemeciliği yer almaktadır. Bu süsleme tekniklerinin ortak ilkesi İslami kurallara uygun motiflere yer verilmesidir. Türklerin İslam dinini kabul etmesi sonrasında özellikle insan figürü tasvir etmek dinen kabul görmediğinden stilize motif ve kompozisyonlara ağırlık verilmiştir. Geometrik motifler ile stilize çiçek, dal ve bitki motifleri ağırlıklı olarak görülmektedir. Desenlerin kompozisyonu sonsuzluk ilkesine dayanmaktadır.

Türk sivil mimarisinde mekânların biçimlenişinde de Türk-İslam yaşam tarzı etkili olmuştur. Türk- İslam yaşam tarzı Orta Asya'daki göçebe dönem alışkanlıklarına bağlı olarak geliştiğinden iç mekânda çok az sayıda eşya kullanılmaktadır. Saraylar ile halkın kullandığı konutların iç mekânları kullanılan eşyaların çeşidi açısından aynıdır. Aradaki tek fark mekânların süslemesidir. Osmanlı toplumunda mekân sahiplerinin toplumdaki 
statüleri ve ekonomik durumları mekânların süslemelerinin zenginliğinden anlaşılmaktaydı. Bu nedenle özellikle saraylarda ve zengin insanların konutlarında iç mekânların süslemelerine önem verilmiştir (Demirarslan, 2011: 69). Şekil- 2'de görüldüğü üzere süsleme teknikleri yörelere göre değişiklik göstermekle birlikte genellikle oturma elemanı olan sedirin sırt dayama minderinin üst kısmından başlayarak tavana kadar olan duvar yüzeyi ile tavan her yörede süslemelerin yoğun olarak yapıldığı kısımlardır.

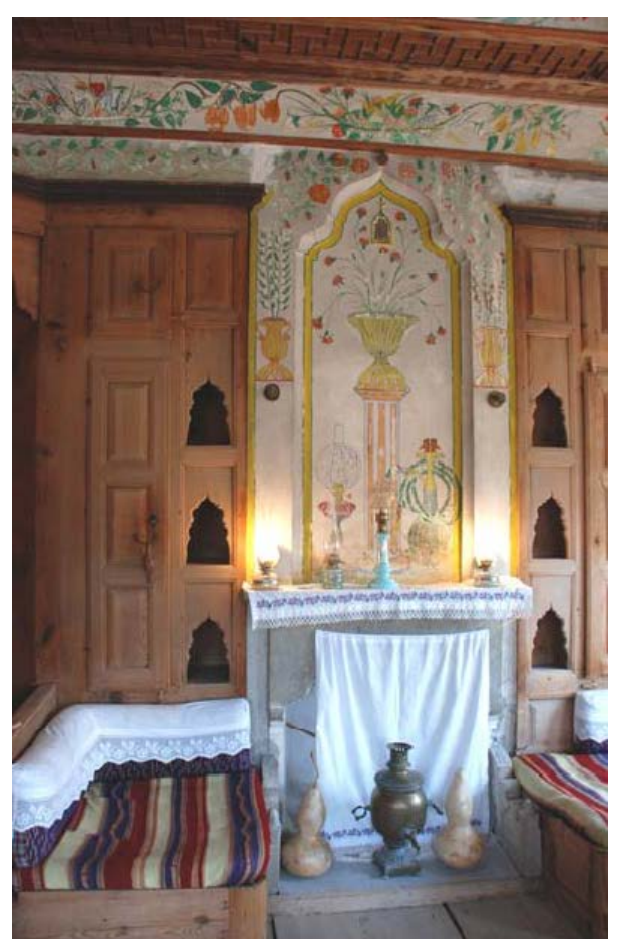

Şekil 2. Safranbolu Yörükköy'den oda dekorasyonunda ahşap duvar süslemeleri ile kalem işi süslemeler (Fotoğraf yazar tarafından belgelenmiştir, 2012).

Bu kısımlarda ahşap çıta ve geçme, alçı fresk teknikleri ile birlikte özellikle 18. yüzyılın ikinci yarısından itibaren başlayarak 19. yüzyılda duvar resmi teknikleri uygulanmaya başlamıştır. Türk sivil mimarisinde 19. yüzyılda uygulanmaya başlayan bu duvar resmi olgusunun en önemli özelliği İstanbul temasının yaygın olarak kullanılmasıdır.

\section{Türk resim sanatında Batılılaşma ve duvar resminin gelişimi}

Türk sivil mimarisinde duvar resminin gelişimine geçmeden önce Türk resim sanatına kısaca değinilmesi konuyu daha anlaşılır kılacaktır. Avrupalı ressamların yaptığı resimler ve sanatçı etkileşimi sayesinde Avrupa Osmanlı'yı tanımıştır. Bu nedenle Osmanlıların Avrupa ile kültürel ilişkilerinde resim sanatı önemli bir yer tutmuştur. Geleneksel Türk resim sanatının özü ise minyatürdür ve genellikle mimarinin bir parçası olarak duvar resmi şeklinde uygulanmıştır. Padişah III. Selim'den itibaren Osmanlı resim sanatı yüzünü Batıya dönmüştür. Özellikle 18. yüzyılın son çeyreğinde Avrupa'dan İstanbul'a birçok ressamın gelerek çalışmalarda bulunması sonucu, bazı Osmanlı devlet adamları da Batı sanatından etkilenmiştir.

Cezar'ın eserinde (1995: 42) vurguladığı üzere; bu etkinin Batılı ressamların çalışmalarından haberdar olan veya onları gören Osmanlı yöneticilerinin düşünce düzeylerinde resme karşı duyulan tutuculuğu gevşetici, öte yandan bazı teknik konularda resmin gereğine inandırıcı, resme yetenekli kimseler üzerinde ise minyatür 
türü resim dışındaki resmin özelliklerini öğrenme imkânını kazandırıcı mahiyette olacağı kuşkusuzdur.

19. yüzyılda Batılılaşma etkisiyle açılan askeri okullarda okuyan ressamlar Ferik İbrahim Paşa, Ferik Tevfik Paşa ve Hüsnü Yusuf, Batılı anlamda resim sanatının ilk temsilcileri arasında yer alırlar. Bu ressamların eğitim için Avrupa'ya gönderilmeleri sonucu ve ünlü Türk ressamı Osman Hamdi tarafından bir sanat okulu olan Sanayi-i Nefise Mektebi'nin de kurulması (1881) ile Türk resim sanatı Batılı tarzda değişikliğe uğramıştır (Eliri, 2010:148; Dilmaç, 2012: 88).

Sonuç olarak, bu dönemde Türk resmi perspektif, desen gibi temel öğelerine sahip ve İslami geleneklere uygun figürsüz manzaraları içeren resimler üretmiştir. Dönemin II. Mahmut (1808- 1839) ve Abdülmecid (1839-1861) gibi sanatsever ve yenilikçi padişahları sanatçıların çalışmalarını desteklemiş ve sonraki dönemin ilk dikkat çekici ressamlar kuşağının, daha atak bir çıkış yapmasına zemin hazırlamıştır. Bu dönemde ayrıca, bazı azınlık ve yabancı sanatçıların etkinliklerinin de artmaya başladığı görülmektedir. Padişahlar yabancı sanatçıları saraya kabul etmiş ve resimlerini satın almış ya da onlara bir takım siparişler vermişlerdir. Batılı tarzda saraylar ve köşkler inşa eden Osmanlı seçkin tabakası bu yapıların iç mekânlarını yeni yaşam tarzına uygun olarak döşemeye ve süslemeye giderek daha fazla önem vermiş ve bu mekânların duvarlarını Batılı tarzda yapılmış yağlı boya tablolarla donatmışlardır. Osmanlı seçkin tabakasının konutlarının içerisinde en fazla intimam gösterilen ve hiyerarşi esasına göre organizasyonu ve dekorasyonu yapılan mekân salondur. Bu salonların duvarlarının dekorasyonlarında kara kalem, suluboya ya da yağlı boya tablolar asılmakta ya da duvar resimleri yer almaktaydı (Yaşar, 2012: 2928).

Ancak, resim anlayışının ve tarzının değiştiği Batıııaşma sürecinde bile iç mekânların süslenmesinde duvar resmi önemini korumuş ve Batılılaşmaya ayak uydurarak gelişmiştir. Duvar resminin kökeni Orta Asya'ya dayanmaktadır. Bu süsleme şekli 8-9. yüzyıl Uygur sanatı ile başlamış ve Osmanlı sanatı ile önem kazanmıştır. Kalem işi olarak isimlendirilen duvar resmi bir fırça yardımı ile sıva, ahşap, deri gibi malzemeler üzerine uygulanan ve tezhip tekniğini andıran bir teknikle duvar, tavan, kubbe gibi mimari elemanlar üzerine uygulanan bir süsleme tekniğidir. Bu sanatı uygulayan sanatçıya da "kalemkâr" ya da "nakkaş" adı verilmektedir (Kuşoğlu, 2010: 122). Freskten farklı olarak kalem işi kuru sıva üzerine uygulandığından daha yüzeyseldir (Gültekin, 2008: 15). Türk mimarisinde özellikle saray ve köşklerin önemli süsleme tekniği olan kalem işi dini yapılarda da uygulanmıştır. Bu tekniğin en önemli ve eski örneklerinden biri Selçuklu döneminde inşa edilen Divriği Ulu Camii'nde (1228-1229) bulunmaktadır. Osmanlı dönemine ait yapılarda da Bursa Yeşil Cami ve Yıldııım Cami, Edirne Muradiye Cami ile Topkapı Sarayı ve Dolmabahçe Sarayı iç mekânlarında önemli örnekler yer almaktadır. Bu tür duvar resimlerinin uygulama alanı Balkanlarda da çeşitli örneklerde görülmektedir (Uçar, 2013: 672).

Duvar resminin Batı etkisiyle gelişimi de Türk resim sanatının Batı etkisinde gelişimi sayesinde olmuştur. Bu etkileşim süreci oldukça uzundur. Arlı'nın eserinde (2000: 11) padişah Fatih Sultan Mehmed zamanında (1432- 1481) davet edilen Avrupalı ressamların yanı sıra nakkaş olarak isimlendirilen duvar ressamlarının Venedik'e gönderilmiş olduğu belirtilmektedir. Gürçağlar'da eserinde (2005: 228) Türk nakkaşların İtalyan sanatçılardan gölgeleme ve modle etme tekniklerini öğrenirken Venedikli ressamların renk konusunda Osmanlı'dan etkilenmiş olduklarını açıklamaktadır. 18. yüzyılın ikinci yarısından sonra duvar resmi başkentte yeni bir resim türü olarak gelişmiş (Gültekin, 2008: 15) ve padişah III. Selim döneminde ( 17611808) duvar resmi sanatı Batıya iyice yüzünü dönmeye başlamıştır. Yine Arlı eserinde (2000: 90) padişah II. Mahmud'un (1785-1839) 1826 yılında çıkardığı bir fermanla 
nakkaşıı̆ı serbest bıraktığını, bu sanatın Frenk, Levanten, Ermeni ve Rum gibi gayrimüslimler tarafından da yapılmasına olanak tanımış olduğunu ve nakkaşları Avrupa'ya eğitime yolladığını söylemektedir. Örneğin; Çırağan Sarayı'nın duvar ve tavan bezemelerini yapan Hacı Mıgırdiç Kalfa ile Sapon Bezirciyan Ermeni asıllı Osmanlı duvar ressamlarıdır. Böylece duvar resminin gelişim süreci hızlanmıştır. Batılılaşma etkisi ile Barok ve Rokoko tarzı motiflerin ve uygulama tekniklerinin ağırlık kazanmasıyla öncelikle Topkapı ve daha sonra da Dolmabahçe Sarayı'nda ve sonrasında da konutlarda Batı tarzı kalem işleri görülmeye başlamıştır. Şekil-3' de Topkapı Sarayı'nda en önemli duvar resmi çalışmalarının yer aldığı padişah III.Ahmed'e ait Yemiş Odası'ndaki resimlerde Barok ve Rokoko stillerinin etkisi açıkça görülmektedir. Çalışır eserinde (2008: 75$)$ bu kalem işlerinde Batı etkisinin yanı sıra Hint- Moğol ve Osmanlı dekorasyon anlayışındaki paralellikleri görmenin mümkün olduğunu vurgulamaktadır. Odanın ahşap duvar yüzeyini dolanan yatay şeritler, dikdörtgen alanlara ayrılmış olup; her birinde nişler içinde vazoda çiçekler ve meyve kâselerinden oluşan kompozisyon yer almakta ve en alt şeritte dikdörtgen alanlarda sepet içinde meyveler görülmektedir. Gültekin eserinde (2008: 15) III. Ahmed'in Yemiş Odası'nı süsleyen bu motiflerin evlerin, köşklerin cephelerini de süslediğini belirtmektedir.
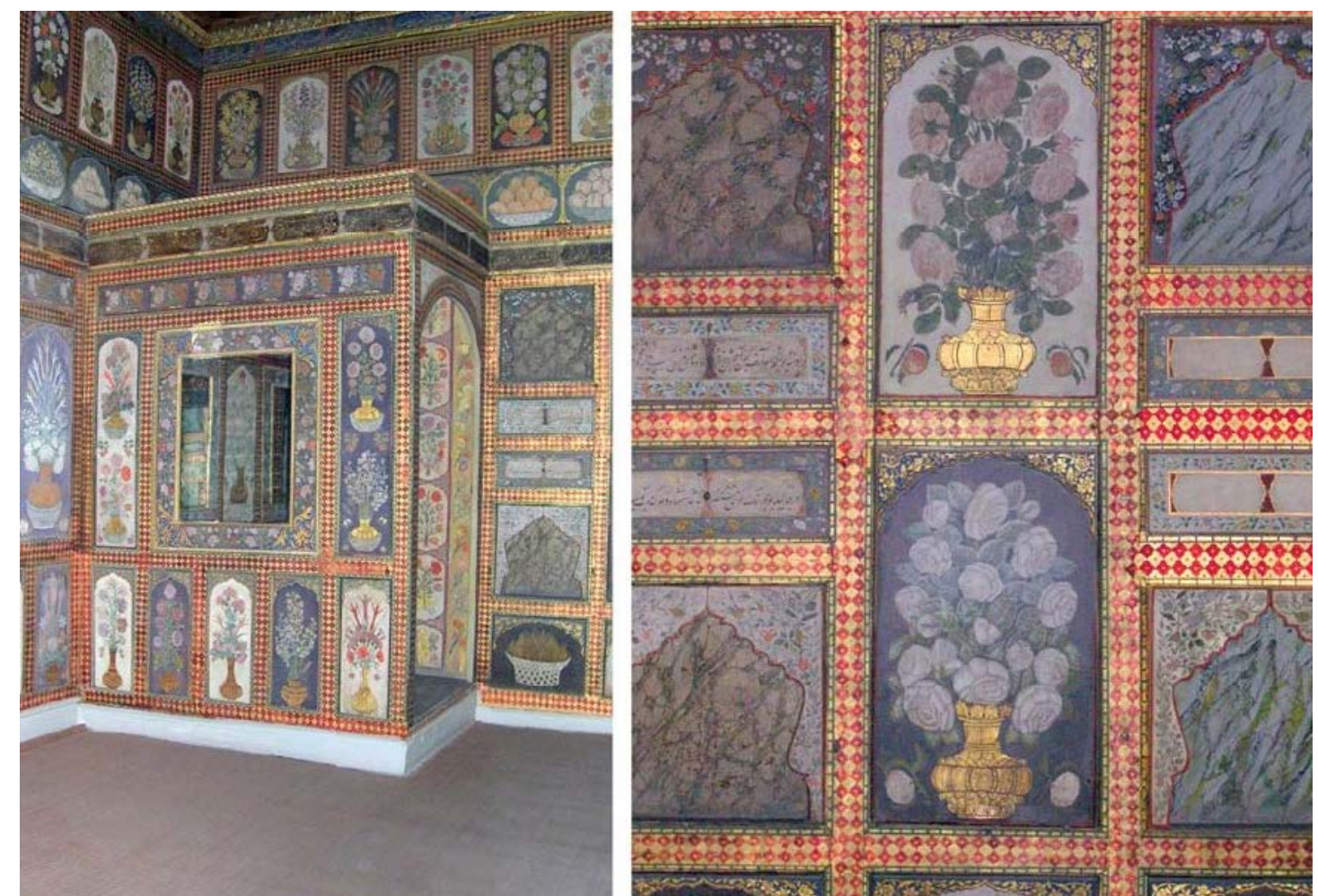

Şekil 3. Yukarıda Topkapı Sarayı iç mekânlarında natüralist anlayışta kalem işi ile süslenmiş Yemiş Odası ve sağda bu kalem işinden bir detay görülmektedir (Fotoğraf yazar tarafından belgelenmiştir, 2012).

Geleneksel Türk sanatında İslam etkisiyle diğer plastik sanat türlerinde görüldüğü gibi duvar resminde de insan figürü kullanılmamış, İslam dini tarafından yapılması kabul görülmeyen tüm canlı figürler yerine daha çok natüralist tarzda motifler kullanılmıştır. Günümüze dek gelen en erken tarihli Osmanlı duvar resmi örneği Topkapı Sarayı harem dairesinde I.Abdülhamid döneminde (1725-1789) yapılmış gözdeler dairesinin üst kat odasının duvarlarını kaplayan 1776 tarihli resimlerdir. 16. yüzyılda saray nakkaşları tarafından natüralist tarzda yaprak, dal ve çiçek motifleri kullanıımıştır. İlerleyen yıllarda İmparatorluğun çeşitli bölgelerinden özenle seçilen ve sarayda 
yetiştirilen nakkaş, tezhip sanatçıları ve ressamlar klasik Osmanlı duvar resmini geliştirmişlerdir. Önceleri saray süsleme tekniği olarak gelişen bu teknik zamanla taşrada yaşayan halk tarafından da benimsenerek bir halk sanatı haline gelmiştir. Osmanlı minyatürünün gelişim çizgisini tamamladığı dönemde kalem işi olarak isimlendirilen bu duvar resmi tekniği 18. yüzyıldan itibaren başlayarak, özellikle 19. yüzyılda Batııılaşma etkisiyle gelişmiş ve İslami kuralların dışına çıkmıştır. Manzara tasvirleri ile birlikte, bina tasviri, gemi ve tren tasviri, natürmort, sembolik motifler, hayvan ve hatta insan figürleri kullanılır olmuştur. Şekil-4'de yine Topkapı Sarayı harem dairesi Valide Sultan odasından bir manzara tasviri örneği üzerinde değişen duvar resmi anlayışı daha iyi algılanmaktadır.

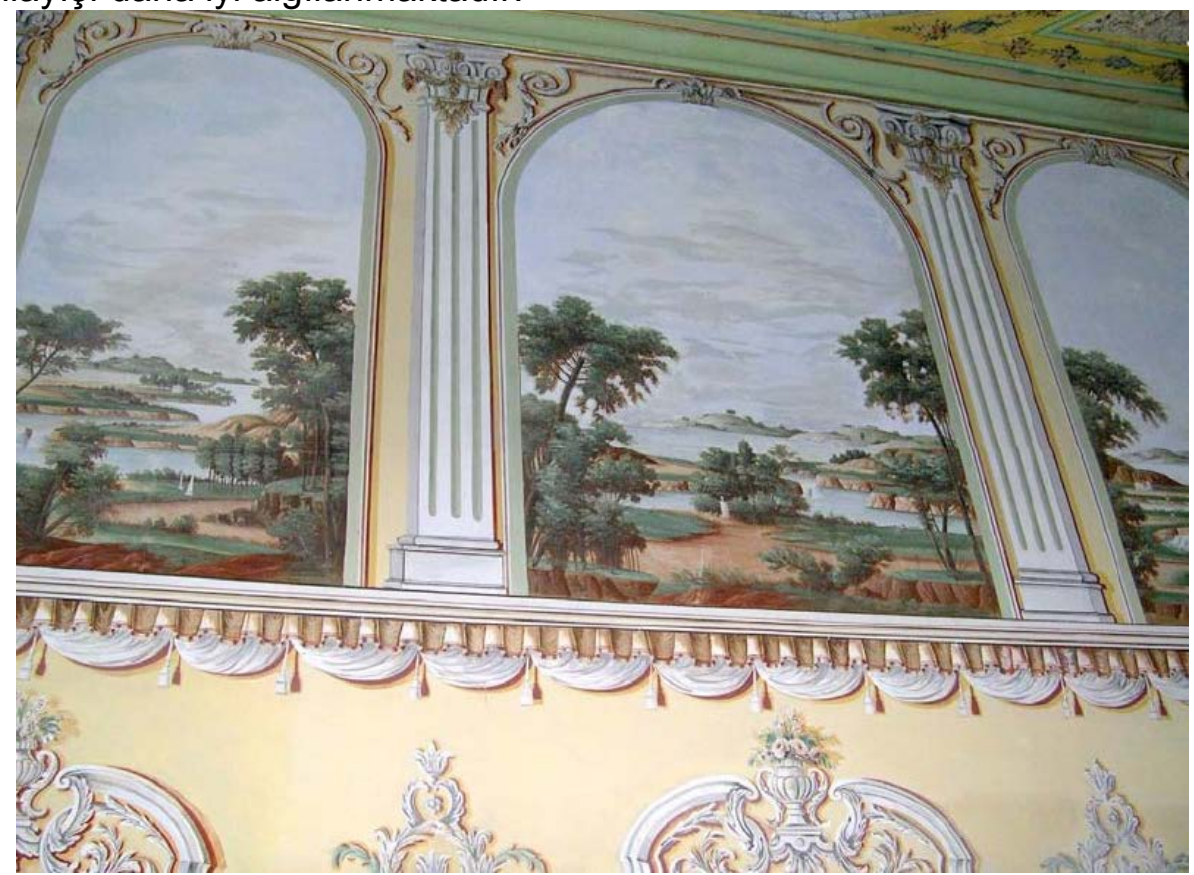

Şekil 4: Topkapı Sarayı'nda Batılı tarzda manzara tasvirleri ile yapılmış kalem işi örneği (Fotoğraf yazar tarafından belgelenmiştir, 2012).

Duvar resminde 18. yüzyılda daha çok Barok ve Rokoko çizgiler taşıyan bezeme motiflerin 19. yüzyıl sonlarına doğru yerini çoğu kez gölgeli ve boyalı bereket boynuzu, kenger yaprakları, fiyonk veya antik vazolar gibi ampir motiflere bıraktığı görülmektedir. $\mathrm{Bu}$ motiflerin çerçevelediği manzara ve natürmortlar ise pek değişmemiştir. Hayali başkent manzaraları veya çevre görüntüleri naif bir yorumla tasvir edilmiştir. Şekil-5'de yine Topkapı Sarayı'nda bir kapı üzerinde yapılmış bu tarz bir duvar resmi örneği görülmektedir. 19. yüzyılda Türk sivil mimarisinde yaygın olarak görülen bu duvar resimleri kompozisyon düzeni, üslup ve teknik yönünden Batı resmi örnekleridir. 


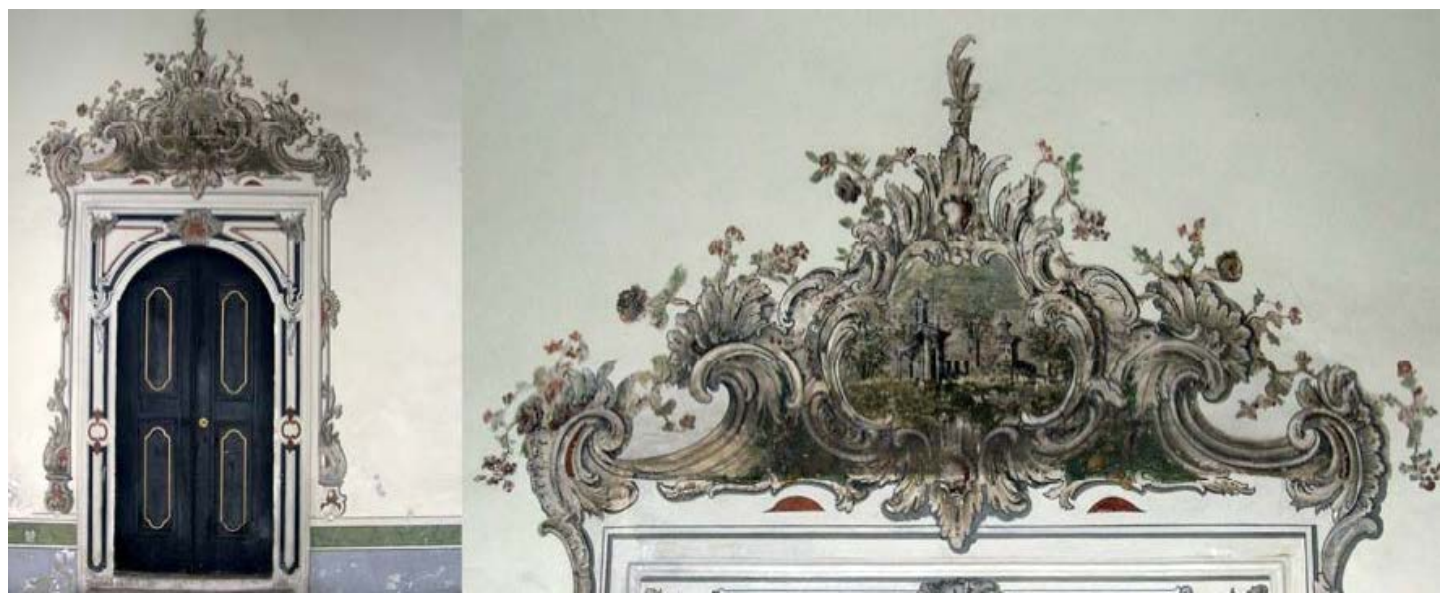

Şekil 5. Topkapı Sarayı'nda Batılı tarzda manzara tasvirleri ile yapılmış kalem işi örneği ve detayı görülmektedir (Fotoğraf yazar tarafından belgelenmiştir, 2012).

19.yüzyılda Avrupa'da duvar resmi yaş sıva üzerine yapılırken, daha önce de belirtildiği gibi Osmanlı'da ise kuru sıva veya ahşap üzerine yapılmıştır (Öndin, 2000: 4). Renda eserinde (1977: 78) bu tekniğin uygulanmasında zemin ahşap ise ahşabın üzerinin ince bir tabaka alçı ya da tutkallı üstübeç ile kaplandığını ve bunun üzerine tutkal veya su ile karıştırılmış boyalarla resim yapıldığını belirtmektedir.

Duvar resimlerinde farklı üslup ve anlayışların olması, çalışan sanatçıların farklı kültür çevrelerinden, değişik duvar resmi atölyelerinden geldiklerini göstermektedir. Resimlerde minyatür etkisinden dolayı az renk kullanılmıştır. Renklerdeki açık-koyu dereceleri titizlikle kullanılmış, ışık- gölge etkisi verilmiştir. Şerit ve pano şeklinde ya da tüm duvarı kaplayacak şekilde yapılan duvar resimlerinin en önemli özelliği Batı tarzında perspektifin ilkel bir şekilde uygulanmasıdır. Türk süsleme sanatları içinde maliyet açısından en ucuz yöntem olduğu ve uygulama teknikleri de diğer tekniklere kıyasla daha kolay olduğu için özellikle halk tarafından iç mekân dekorasyonunda tercih edilmiş ve 19. yüzyılda başkent İstanbul, Anadolu ve Balkan şehirlerinde sivil mimaride en yaygın olarak kullanılan duvar resmi teması İstanbul olmuştur.

\section{Batılılaşma etkisiyle gelişen duvar resminde İstanbul temasının örnekler üzerinde incelenmesi}

Belirtildiği üzere İstanbul Batılılaşmanın merkezi olarak taşrada yaşayan insanların ilgisini çekerken oryantalist Batılıların da ilgi odağı haline gelmiştir. Ancak, Anadolu ve Balkanlardaki halk İstanbul'a ve Batılılaşmaya karşı duyulan özlemi konutlarındaki duvar resimlerinde sıklıkla dile getirmeyi tercih etmişlerdir. Çünkü İstanbul Batıya açılan bir pencere olarak görülmüştür. İstanbul'da hızla Batılılaşan yaşam tarzı, değişen yaşam biçimi gıpta ile izlenmiş ve örnek alınmış; hissedilen özlem duvar resimlerine konu olmuştur. Konutlarda İstanbul temalı duvar resimleri konut sahiplerinin toplumdaki statüsünü belirten bir imge olarak kabul görmüştür. Hatta İstanbul konulu resimler sadece duvarlarda değil, tepsi, sehpa, saat gibi eşyaların üzerinde de yapılmıştır. Yıldız Porselen Fabrikası'nda üretilen vazo gibi eşyalarda da İstanbul görünümleri ağırlıktadır. Aynı zamanda Avrupa'da Osmanlı pazarına sürmek için üzeri İstanbul konulu resimlerle süslü eşyalar yapılmış ve konu ticari bir bakış açısı ile ele alınmıştır. Şekil6'da Avusturya Macaristan İmparatorluğu damgalı ve Osmanlı pazarı için üretilmiş gümüş bir sigara tabakası üzerinde ve İsviçre yapımı bir cep saati üzerinde İstanbul tasviri açıkça görülmektedir. 

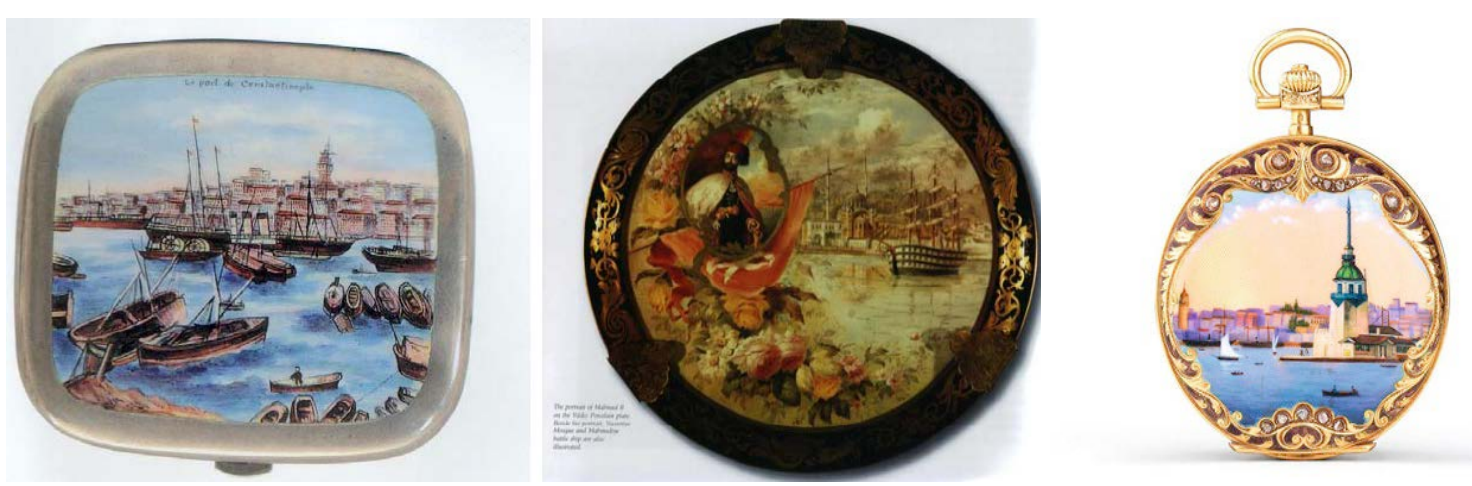

Şekil 6. Solda Avusturya-Macaristan İmparatorluğu damgalı, Osmanlı pazarı için üretilmiş 20. yüzyıl başına tarihlenen bir sigara tablası (Antique Decorative Objects Kataloğu, 2003: 77), ortada Yıldız Porselen Fabrikası'nda üretilmiş bir tabak (Akşit, 2005: 43) ve sağda 19.yüzyıl sonu- 20. Yüzyıl başına tarihlenen İsviçre yapımı bir cep saati üzerinde İstanbul tasvirleri görülmektedir (URL-2) .

Duvar resimlerinde İstanbul temasının seçilmesindeki diğer nedenlerin başında Batı etkisiyle açılan askeri ve teknik okullarda yetiştirilen ressamların eğitimlerinde gördükleri dersler sonucu edindikleri bilgilerin topografya ve doğaya karşı ilgiyi artırması gelmektedir. Ayrıca daha önce de belirtildiği üzere resimde perspektif konusu, ışık- gölge dereceleri ve tonal renk ilişkileri önem kazanmıştır.

İstanbul temalı duvar resimleri hayali resimler ve gerçekçi resimler olarak iki farklı şekilde yapılmıştır. İstanbul'daki örnekler İstanbul'u gerçekçi betimlemelerle resmederken, Anadolu ve Balkanlardaki örneklerde ressamlar İstanbul'u hayali olarak resmetmişlerdir. Gürçağlar eserinde (2005: 251) hayali ya da gerçekçi olsun İstanbul imgesinin Osmanlı sanatçısı için ifade ettiği özelliğin, kendi ülkesinin başkenti, halifesinin yaşadığı kent, yaşama biçiminin, kültürel etkileşimin başlangıç noktası olduğunu vurgulamıştır.

Bu tekniğin İstanbul'daki gerçekçi örneklerinde kent görünümleri, panoramik görünümler, İstanbul'dan manzaralar yer almaktadır. Bazı örneklerde de köprü, dağ, ağaç, çeşme, su ve binalar yer alır. Hayali resimler genellikle akıldan ya da gravürlerden, kartpostal ve 19. yüzyılda ise fotoğraflardan etkilenerek yapılmıştır. Ünlü Türk fotoğrafçıları Abdullah Biraderler'in İstanbul'u fotoğraflayarak belgelemeleri ve çalışmalarını 1867 Uluslararası Paris Sergisi'ndeki Türk pavyonunda sergilemeleri ve bu fotoğraflardan basılan kartpostalların hem Avrupa'da hem de İmparatorluk sınırları içinde etkili olmaları bu konuda önem taşımaktadır (Arlı, 2000:121). Resimlerdeki bina tasvirlerinin bir bölümü geleneksel Türk konutlarına benzemektedir. Konutların iç mekânlarını süsleyen bu duvar resimleri ince, uzun, geniş açılı panoramik resimlerdir. 18. yüzyılda antik kültürün ortaya çıkmasıyla harabe görünümleri de resme girmiştir. Resimlerde nakkaşlar çoğunluğu da İstanbul'da bulunan çeşitli yapıları bir araya getirerek değişik bir anlatım oluşturmuşlardır. Bu uygulamaya "kapris" adı verilmektedir (Renda, 1985: 153). Topkapı Sarayı'nın özellikle harem bölümünde bu tür duvar resimlerine rastlanır. Bunlar tavan eteklerini dolanan şeritler ve duvarların üst bölümlerinde Barok ve Rokoko tarzı süslerin arasına yerleştirilen pano resimlerdir. Bu şeritlerde köşkler, çeşmeler, köprüler, harabeler ve ağaçlar yer alır. Boğaz, Haliç, Galata, saraylar, Göksu Çeşmesi, Kızkulesi, Kalamış Koyu, Fenerbahçe Feneri görünümlerine yer verilen resimlerde ayrıntılarıyla betimlenen akarsu kıyısında köprüler, cami, çeşme, ağaç, bina, bahçe ve havuz imgeleri perspektifle birlikte doğal toprak renklerle belgeleyici bir nitelik kazanmıştır. 
Topkapı Sarayı'ndaki örneklerde padişahların saltanat dönemlerine göre farklılıklar görülmektedir. Örneğin; I .Abdülhamid döneminde tavan eteğini dolanan şeritler içinde tek rengin tonları tercih edilirken; III. Selim döneminden itibaren geniş alanlarda kartuş ve madalyonların içine yerleştirilen gerçekçi İstanbul manzaraları yapılmıştır (Tekinalp, 2006: 14). Şekil- 7'de Haremde Valide Sultan Odası Sofası üst katında yer alan bir duvar resmi görülmektedir. Resimde Topkapı Sarayı'nın bahçesi ve içinde yer alan köşkler resmedilmiştir. Bu anlayış kısa sürede Osmanlı İmparatorluğu sınırları içinde yayılmış ve geleneksel resim anlayışına ışık- gölge uygulamaları gibi Batılı kavramlar girmiştir. III.Selim'in meşk odasında da benzer bir duvar resmi bulunmaktadır.

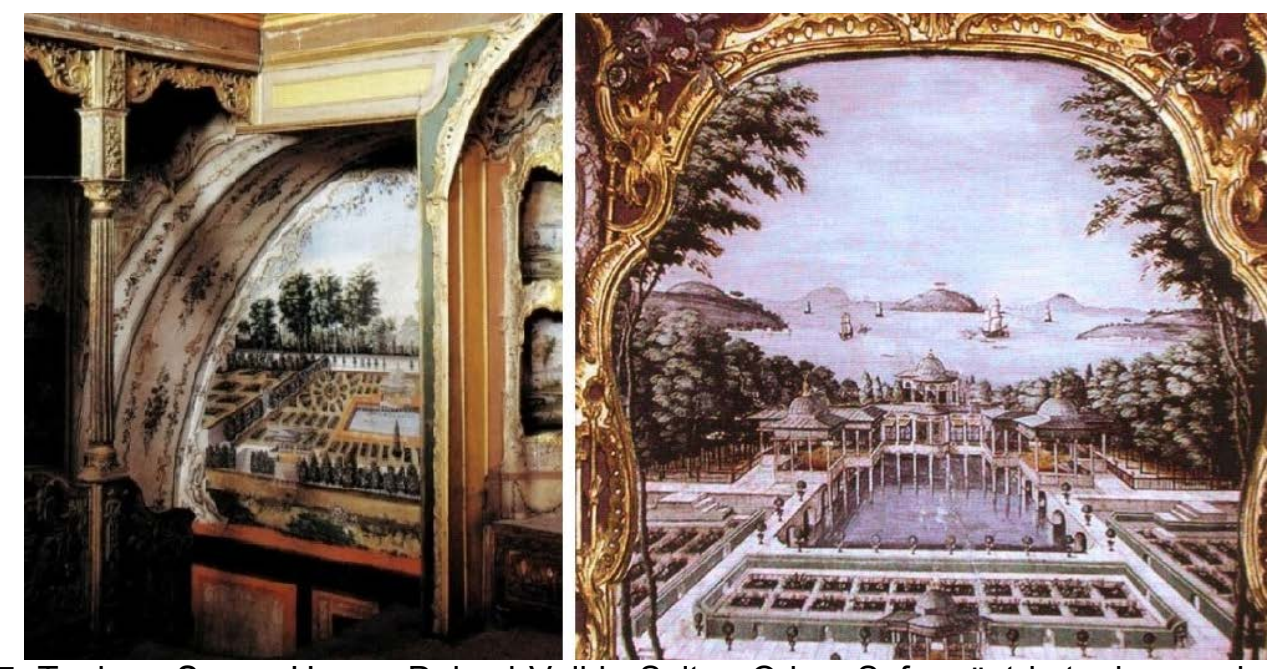

Şekil 7. Topkapı Sarayı Harem Dairesi Valide Sultan Odası Sofası üst katında yer alan duvar resmi ve detayı (Tekinalp, 2006:122), (Soldaki fotoğraf yazar tarafından belgelenmiştir).

İstanbul'da yapılmış örneklerde İstanbul camileri konu olarak yaygın bir şekilde kullanılırken İstanbul dışında yapılmış örneklerde cami imgesi çok fazla bu resimlerde yer almamıştır. Kullanılan renklerin ise hemen tüm örneklerde aynı olduğu dikkati çekmektedir. İlk dönem örneklerinde kök boyalar kullanılmıştır. Tavanlar, tavan etekleri, kubbe içi, kemer içi, pandantifler ve duvarlarda yer alan resimlerde 19. yüzyılın ikinci yarısından sonra yeni bir teknik olarak yağlıboya kullanılmıştır. Yağlıboya duvar resimlerine parlak bir görünüm kazandırmıştır. Özellikle tavanlarda geometrik bölmeler veya madalyonlar içine yerleştirilmiş hayali İstanbul manzaraları ve natürmortlar çeşitlilik kazanmıştır.

18. yüzyılda İstanbul'a gelen yabancı ressamların İstanbul görünümleri ve manzara resimlerinin etkileri de duvar resimlerine yansımıştır. 19.yüzyılın ikinci yarısından itibaren teknikle beraber konularda da değişiklik olmuştur. Konu olarak İstanbul'un manzaralarının yanı sıra Türk mimarisine yabancı Avrupa manzaraları, şato, kule, kır ve av sahneleri, saat kulesi imgeleri seçilmiş ve duvar resmine İslami kurallara ters olmasına rağmen insan figürü girmiştir. Bu tür konular yabancı ressamların yaptığı tablolardan kopya edilmekteydi. Bu duvar resimlerinde üslup ve kompozisyon düzeni açısından Batı resim sanatı özelliklerinin uygulanması söz konusudur. Taşra ustaları da İstanbul manzaralarına özellikle yer vermişlerdir. Duvar resimlerinde kalıplaşmış görünümlerin tekrarına bu resimlerde devam edilmiştir.

19. yüzyılın ikinci yarısından sonra bu tarz duvar resimleri ile süslenmiş mekânlara Dolmabahçe, Beylerbeyi, Çırağan ve Yıldız Sarayları, Ihlamur ve Göksu Kasırları ile İstanbul ve diğer kentlerdeki çeşitli köşk ve kasırlarda rastlanmaktadır. Bu dönemde Batılılaşmanın etkisi mimariyi ve iç mekân süslemelerini büyük ölçüde etkilediğinden bu saray ve kasırlar yeni resim anlayışının yoğun şekilde uygulandığı yapılar olarak dikkati 
çekmektedir. Minyatürün ardından gelişen duvar resmi böylelikle yaygınlaşmıştır. II.Abdülhamid döneminde (1842-1918) saray çevresinde adı belirginleşen Ali Bey ve Mehmet Ali Paşa gibi bazı Türk ressamların tuval resminin yanı sıra saray ve köşklerin tavan ve duvarlarında da resim yapmış oldukları görülmektedir (Öner, 1992: 69). İstanbul temalı duvar resimlerini uygulayanlar sadece Türk sanatçılar olmamıştır. Özellikle yabancı mimarların tasarlamış oldukları azınlık evlerinde de bu tarz duvar resimlerine rastlanmıştır. Heybeliada Hulusi Bey Köşkü, Büyükada Kalvokeresis Köşkü, İstanbul Kavafyan Konağı belirlenen örnekler arasında yer almaktadır.

19. yüzyılda Dolmabahçe Sarayı Batı tarzı duvar resminin gelişiminde en önemli mekân olmuştur. Dolmabahçe Sarayı İstanbul temalı duvar resimlerinin iç mekân tasarımı açısından etkilerinin görüldüğü bir yerdir. Geleneksel Türk sivil mimarisi stilize ve geometrik motiflerden oluşan sade bir dekorasyon anlayışından bu duvar resmi uygulaması ile Batılı anlamda bir görünüme bürünmüştür. Batı tarzı duvar resmi uygulamalarının Barok ve Rokoko etkisiyle geliştiği göz önünde bulundurulursa, hiç kuşkusuz bu hususta Osmanlı elçilerinin gezip hayran kaldığı Versaille Sarayı'nın iç mekânlarının etkisi büyüktür. Özellikle Dolmabahçe Sarayı'nın Versaille Sarayı'ndan esinlenerek inşa edilmesi ve Séchan gibi ünlü dekoratörlerin bu sarayın dekorasyonunda görev almaları duvar resminin Türk sivil mimarisinde yaygınlaşmasına neden olmuştur. Bu resimlerde dikkati çeken husus bir oda veya mekânın genellikle aynı üslup veya sanatçı grubu tarafından yapılmış olduğu düşüncesidir. Şekil-8'de görüldüğü gibi Dolmabahçe Sarayı'nın 212 numaralı odasında bulunan İstanbul manzarası İstanbul'un önemli yerleri ile sarayın konumunu belgeleyen gerçekçi betimlemeler içermektedir.
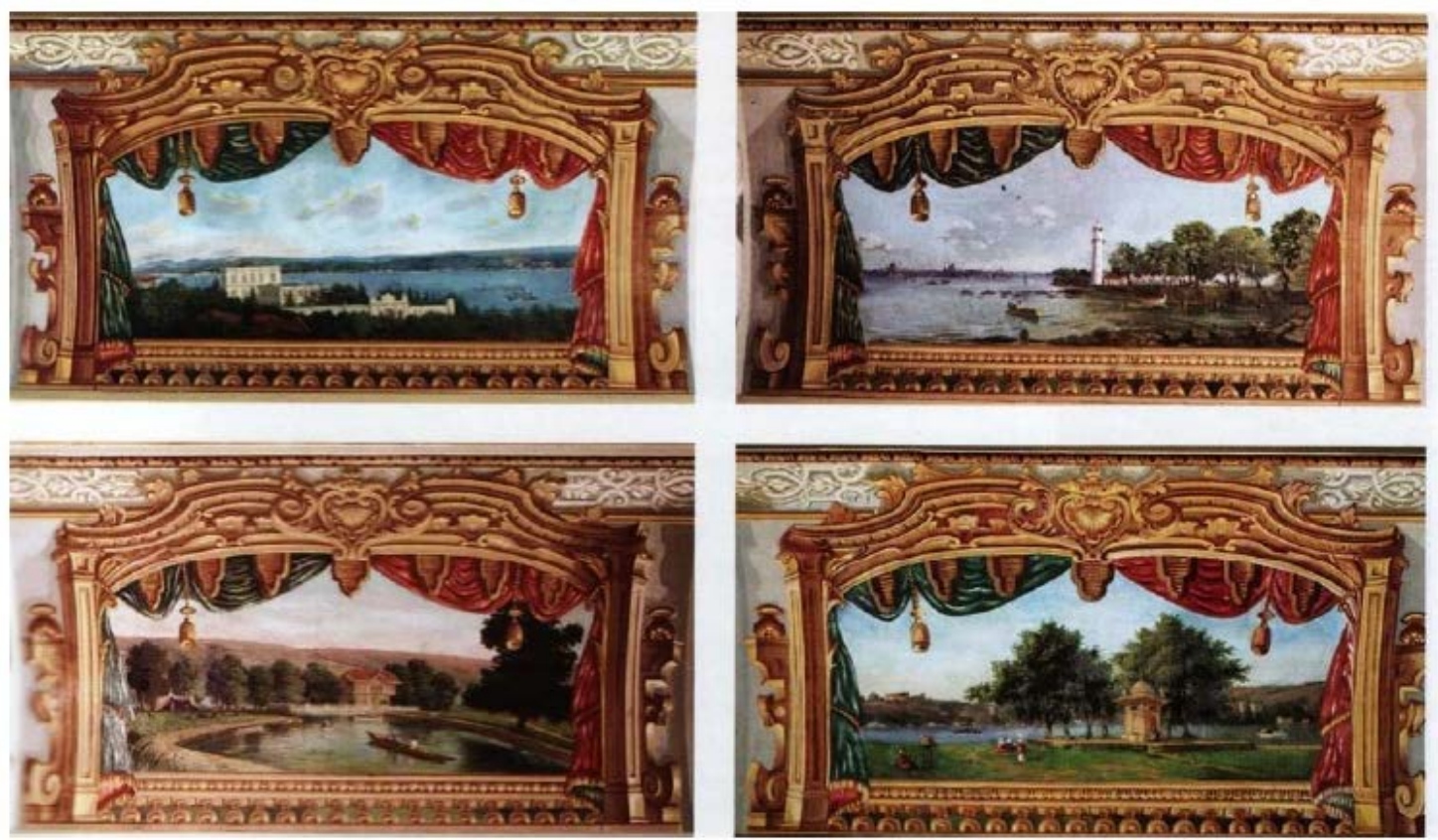

Şekil 8. Dolmabahçe Sarayı 212 numaralı odada Dolmabahçe Sarayı'nın tasviri (Tekinalp, 2006: 125).

Avrupai görünüme kavuşan sarayın iç mekânlarında duvar süslemeleri ile uyumlu Batı tarzında mobilyalar ve mefruşat kullanılmaya başlanmış ve bu uygulama konutlara da hızla yayılmıştır. II. Abdülhamid Dönemi'nde Osmanlı Sarayı'nın Yıldız Sarayı'na taşınmasından dolayı bir özlem simgesi olarak İstanbul'da ve İstanbul dışındaki örneklerde Dolmabahçe Sarayı da konu olarak bu resimlerde kullanılmıştır. Esasen bu resimler dönemin padişahı II.Abdülhamid'in sürdürdüğü dışa kapalı politik yaklaşımına karşı bir tepki olarak ortaya çıkmıştır (Tekinalp, 2006:121). 
İstanbul dışında Anadolu ve Balkanlardaki şehirlerde zengin konutlarında da İstanbul manzaralarını konu alan örneklere rastlanır. Anadolu'da Kocaeli, Tokat, Merzifon, Amasya, Bayramiç, Birgi, Datça, Safranbolu bu örneklerin yer aldığı şehirlerden sadece birkaçıdır. Özellikle İmparatorluk sınırları içinde yaşayan azınlıkların Batılılaşma döneminde Avrupa ile ticari ilişkiler içinde olması Batı tarzı süsleme tekniklerinin İstanbul dışındaki yapılarda da yaygınlaşmasına neden olmuştur. Tokat'da bulunan Latifoğlu Konağı'nın havuz başı odasının duvarları kalem işi panolar halinde hayali İstanbul tasvirleri ile süslenmiştir. Çanakkale Bayramiç'de bulunan Hadımoğlu Konağı, Antalya Tekelioğlu Evi, Safranbolu Yörükköyü Sipahioğlu Konağı, Birgi Çakıroğlu Konağı, Rize Çağlayan Köyü'nde yer alan Okman evi, Kocaeli Dilovası Demirciler Konağı, Derince Beş Divanlı Rıza Bey Konağı'nda yine hayali İstanbul manzaralarının yer aldığı duvar resimleri bulunmaktadır.

Şekil-9'da görüldüğü üzere Okman evinin başodasında yer alan hayali İstanbul resmi ocağın iki yanındaki duvarda ve odanın sağır duvarında yer almaktadır. Resim ahşap üzerine yapılmıştır. İstanbul manzarası ocağın bitiş yüksekliğinden itibaren odanın duvarlarını kapsayan uzun bir şerit halindedir. Resim kompozisyonunda buharlı gemiler ve deniz feneri ile boğaz kıyısı imgeleri yer almaktadır. Yine Şekil-9'da görüldüğü üzere bu imgelerin yanı sıra tren imgesi ile birlikte kaktüs bitkisi imgeleri İstanbul ile ilgisi olmadığı halde yer almaktadır. Hayali İstanbul manzarasını şeridin altındaki geniş yüzeyde yapılmış bulunan çiçek motifleri tamamlamaktadır. Duvar resminin ocağın üzerindeki süslemelerle de bir ahenk içinde olduğu dikkati çekmektedir.

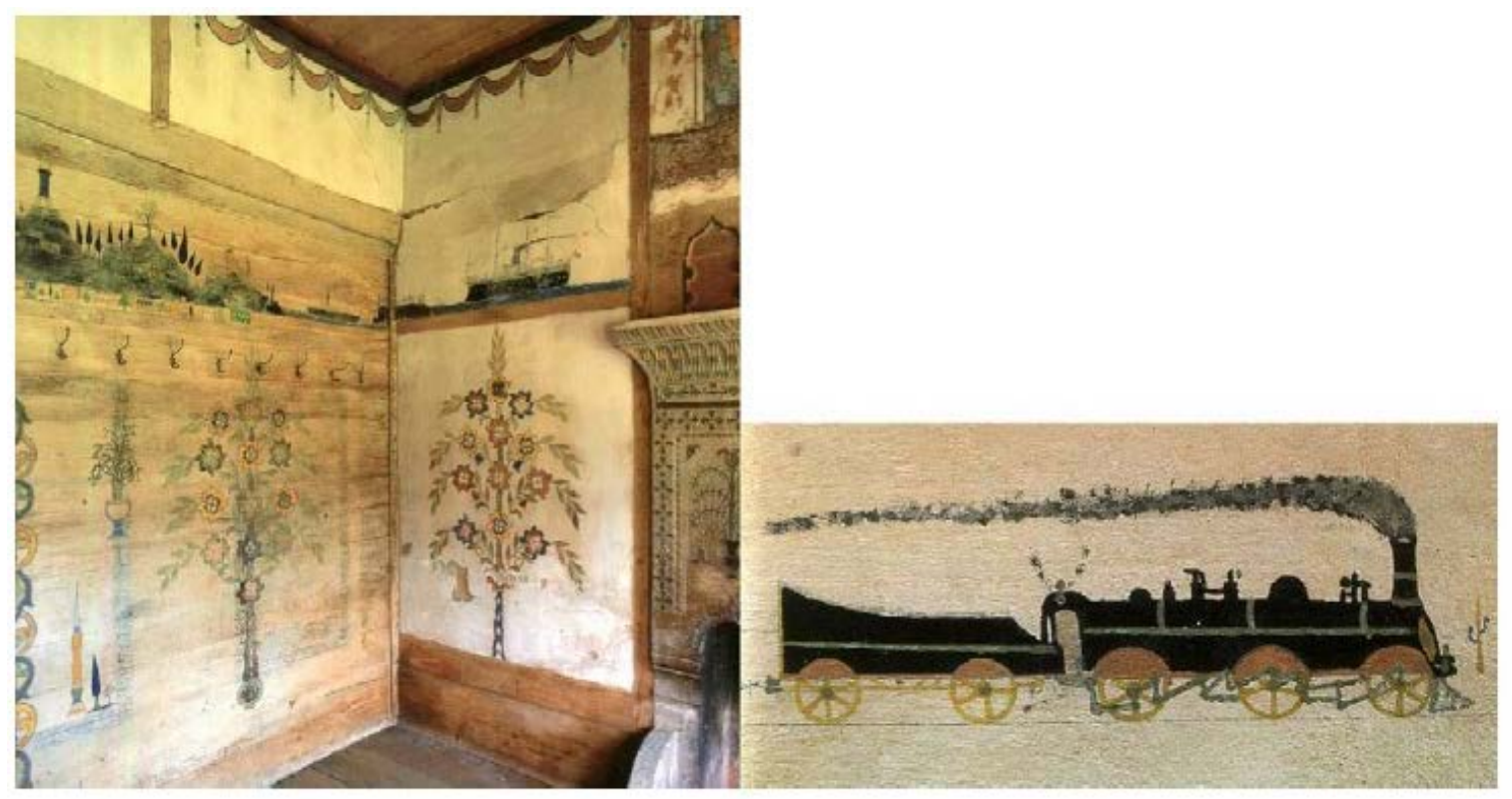

Şekil 9. Solda Rize Okman evinin başodasında yer alan İstanbul konulu duvar resmi ve sağda bu duvar resminde yer alan buharlı tren tasvirinden detay görülmektedir (Batur, 2005: 16).

Şekil-10'da Bursa Yenişehir'de bulunan Şemaki evinin başodasındaki Haliç tasviri görülmektedir. Odada dolap üzerinde şerit halinde yer alan bu resmin 19. yüzyılın son çeyreğinde yapıldığı tahmin edilmektedir. Gürçağlar'ın ifadesiyle (2005: 250) bu duvar resmindeki hayali İstanbul manzarası kompozisyon şeması ve bakış açısı yönünden 1493 'te Wolgemuth tarafından çizilen İstanbul betimlemesiyle benzerlik göstermektedir. $\mathrm{Bu}$ manzarada ön planda ince bir kara şeridi üzerinde bitkisel bir doku dikkati çekmektedir. Resmin orta noktasında yer alan İstanbul Boğazı'nın ortasında bir adacık üzerinde muhtemelen Kızkulesi'ni temsil eden konik çatılı bir kule yer almaktadır. Resimde İstanbul'un meşhur konakları çok sayıda yer almakta, cami ve yelkenli gemi 
imgeleri resmi tamamlamaktadır. Kızkulesi'nin temsili olarak çizilmesi bu resmin hayali olarak yapıldığını göstermektedir.

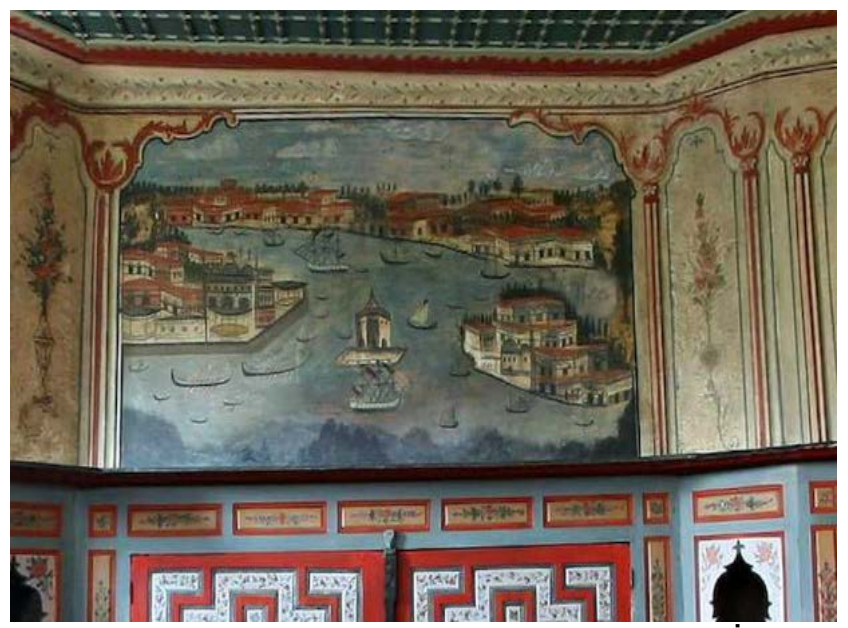

Şekil 10. Bursa Yenişehir'de bulunan Şemaki evinin başodasındaki İstanbul konulu duvar resmi (Fotoğraf yazar tarafından belgelenmiştir, 2012).

Şekil-11'de görüldüğü üzere Safranbolu yöresi Yörükköy'de bulunan Sipahioğlu Konağı'nın başodasında yer alan İstanbul konulu duvar resmi oldukça dikkat çekicidir. Resim tavan eteğinin hemen alt kısmında küçük bir şerit pano şeklinde yapılmıştır. Bir saat kulesi ve yüksek bir yapı önünde demir atmış bir gemi tasviri ile hayali İstanbul manzarası içeren kapris uygulaması ahşap üzerine yapılmış güzel bir kalem işi örneğidir. Resimde buharlı gemi üzerinde bulunan Türk bayrağı bir odak noktası oluşturmaktadır.

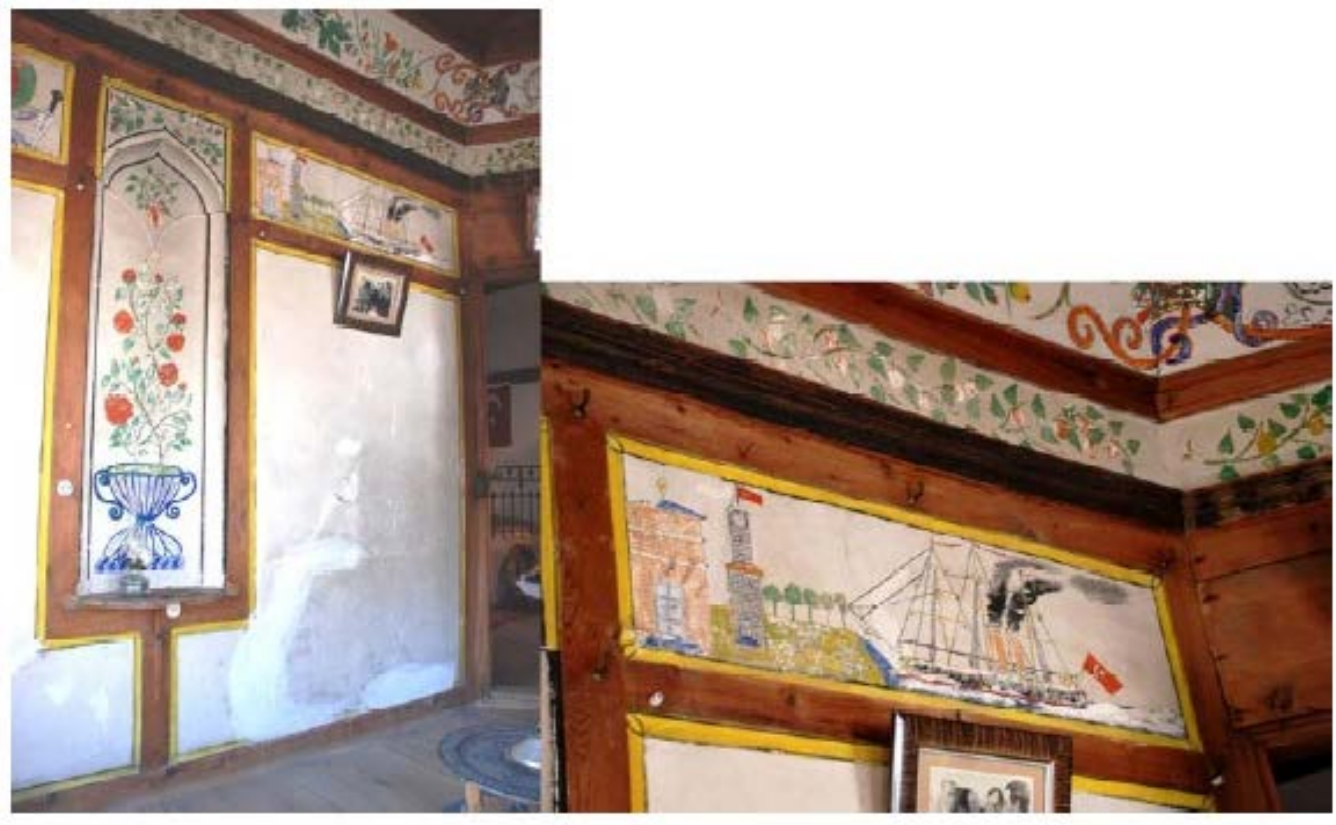

Şekil 11. Safranbolu Yörükköy'de Sipahioğlu Konağı başodasında İstanbul temalı duvar resmi ve bu resimden detay görülmektedir (Fotoğraf yazar tarafından belgelenmiştir, 2012) .

Birgi'de bulunan Çakıroğlu Konağı'nın başodasının giriş duvarında dolabın üst kısmında yer alan İstanbul temalı resimde yine Kızkulesi imgesi ile birlikte Boğazın iki yakası ve tarihi yarımada resmedilmiştir. Şekil-12'de görüldüğü gibi kompozisyonda yoğun bir konut dokusu dikkati çekmektedir. Resim gerek kullanılan renkler gerekse de anlayış açısından odada yer alan diğer süslemelerle uyum içindedir. 


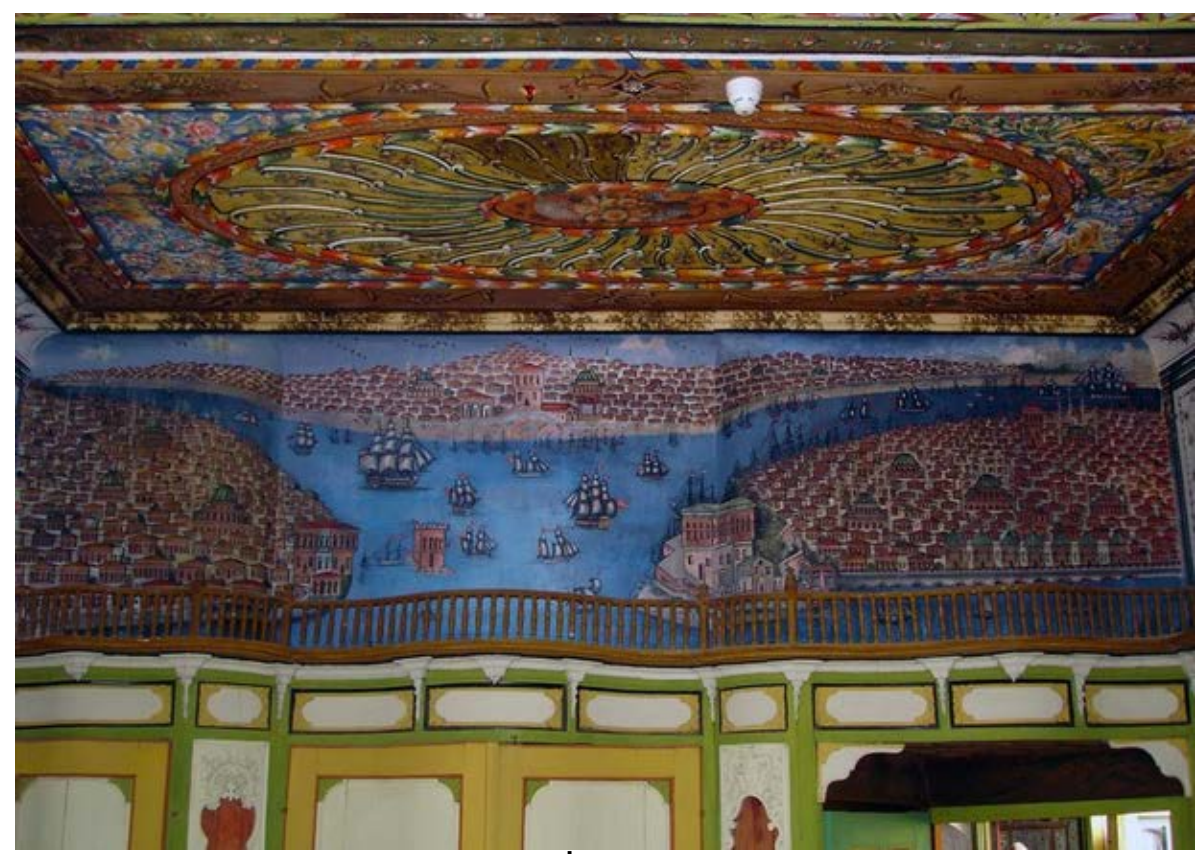

Şekil 12. Birgi Çakıroğlu Konağı'nda yer alan İstanbul konulu duvar resmi (Kuban, 2007: 479).

Trakya'yı İstanbul üzerinden Anadolu'ya bağlayan güzergâh üzerinde bulunan Kocaeli'nin başta merkez ilçesi olmak üzere diğer ilçelerinde de kalem işleriyle bezenmiş yapılara rastlanmaktadır. Hatta başkent İstanbul'a olan yakınlığı nedeniyle, İstanbul'dan birçok sanatçının bölgeye gelerek buradaki konutları süslemek için çalıştıkları söylenmektedir (Çelik ve Ersoy, 2016: 1656). Kocaeli'nin Dilovası ilçesine bağlı Demirciler Köyü'nde yer alan Demirciler Konağı da duvar resimleri ile bezeli dekorasyonu ile öne çıkan bir örnek olup; bu duvar resimleri arasında İstanbul teması önem kazanmaktadır. İstanbul'un ve başka kentlerin panoramik görünümleri hayali ve gerçek betimlemeler olarak yapılmıştır. Şekil- 13 'de konağın başodasında yapılmış İstanbul tasviri olması muhtemel bir kıyı kenti tasviri görülmektedir. Gemilerin denizde çift yönlü yol alıyor olması ve ön planda yer alan kale burcu bu düşünceyi desteklemektedir.
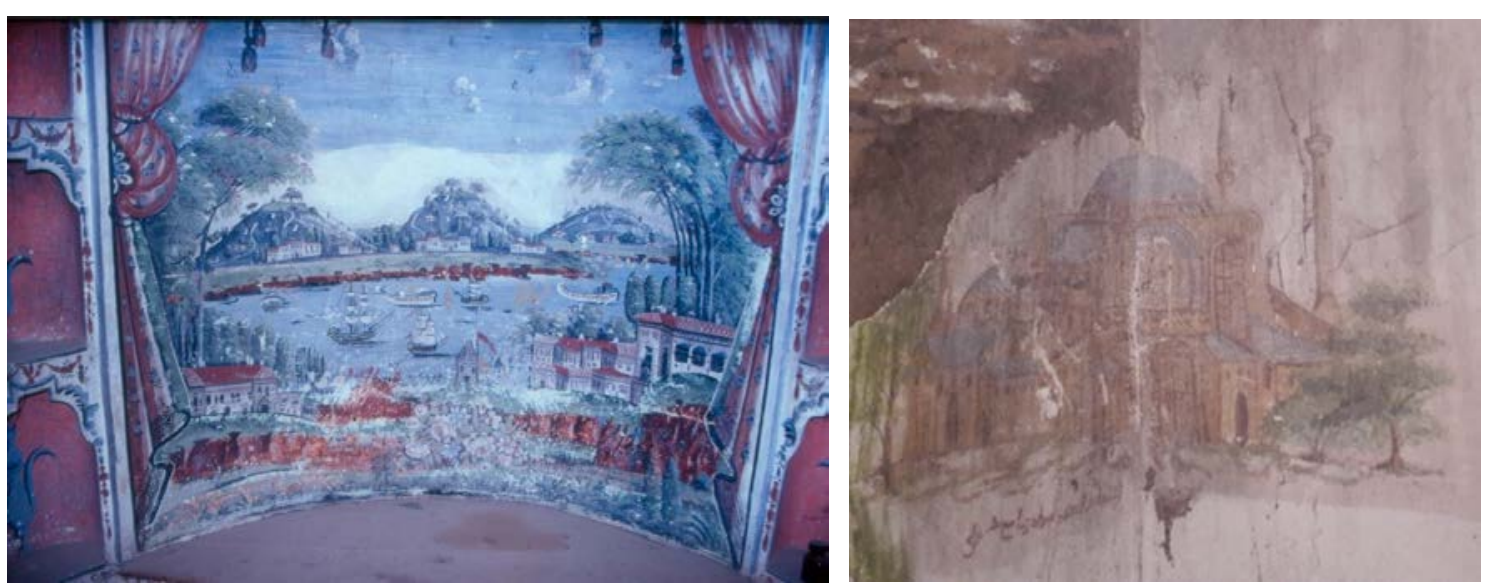

Şekil 13. Demirciler Konağı başodasında yer alan kıyı kenti tasviri (URL-3) ve Beş Divanlı Rıza Bey Konağı'nda Ayasofya tasviri görülmektedir ( Çelik ve Ersoy, 2016: 1663).

Kocaeli'den bir başka örnek de Derince ilçesinde bulunan Beş Divanlı Rıza Bey Konağı'dır. Duvar resimleri konağın iki odasında bulunmaktadır. Bu resimler içinde Ayasofya tasviri öne çıkmaktadır. Bilinen duvar resimleri arasında fazla ele alınmayan 
bir tasvir olan Ayasofya bu örnekte büyük bir ustalıkla ve gerçekçi bir biçimde gösterilmiştir. Çelik ve Ersoy eserlerinde (2016: 1655) tasvirde Ayasofya'nın iki ana payanda arasındaki büyük kemere bakılarak resmedildiğini vurgulamaktadır. Yapının doğru bir şekilde anlatımı bir fotoğraf ya da gravürden yararlanılarak üretilmiş olduğunu kanıtlamaktadır. Tasvirin altında yer alan "Ayasofya Cami-i Şerifi” yazısı da önemli bir kanıttır.

Balkanlardan önemli örnekler de Yunanistan'ın Ambelakia şehrinde bulunan iki konutta görülmektedir. Mavros evi ile Efthymiadis evlerindeki örneklerde İstanbul, Galata köprüsü ile Kızkulesi hayali bir şekilde Rum bir usta tarafından resmedilmiştir. Şekil14 'de görülen Ambelakia'da Georgios Mavros evinin birinci katındaki odada bulunan İstanbul betimlemesinde kenti oluşturan kara parçaları kompozisyonun iki yanına yerleştirilmiştir. Kompozisyon yarı kuşbakışı, plan- resim özelliği göstermektedir. Resmin sağındaki kara parçasında iki- üç katlı, yumuşak renk tonlamalarıyla oluşturulmuş yan yana ve arka arkaya yerleştirilmiş konutlar görülmektedir. Denizde hemen tamamı yandan gösterilmiş yelkenli tekneler ve sandallar yer almaktadır. Resimde açık- koyu yeşille betimlenmiş servi ve çam ağaçları vardır. Tek bakışı bir perspektif uygulanmıştır. Zeminin yeşil ve mavi renkler ile gösterilmesi gerçeklik yanılsamasına yönelik bir çalışma yapıldığını göstermektedir. Ağaç ve konutlarda aynı rengin açıklı koyulu kullanılması ile hacim etkisi yaratılmıştır. Evin ikinci katındaki odada yer alan resimde ise kompozisyonun en geniş yatay şeridini deniz meydana getirmektedir. Kızkulesi bu resmin odak noktasını oluşturmaktadır. Kızkulesi'nin bu resimlerde yer almasının bir nedeni de Bizans yapısı olmasıdır. Yunanistan'daki örneklerde cami, saray gibi imgeler yerine Bizans uygarlığına işaret eden Kızkulesi İstanbul görüntüsünü tamamlayan bir unsur olarak kompozisyonun içindeki yerini almıştır (Gürçağlar, 2005:158).

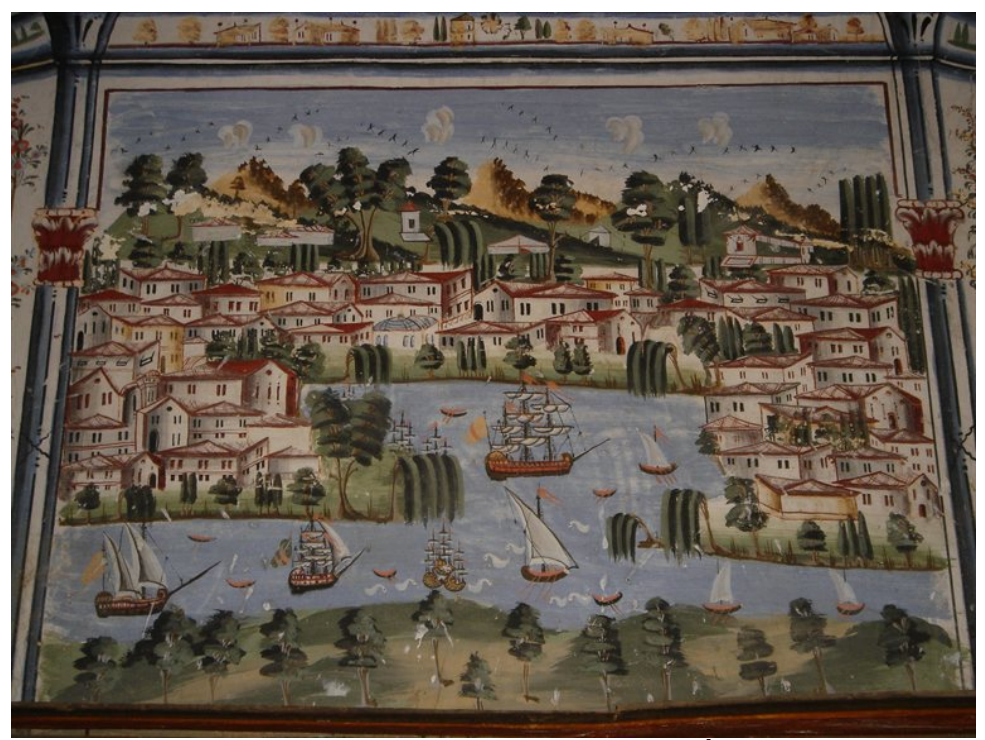

Şekil 14. Ambelakia'da Georgios Mavros evinde yer alan İstanbul konulu duvar resminden detay görülmektedir (Akın, 2001: 84-85,URL-4).

Efthymiadis evinde yer alan resimde de yine Kızkulesi imgesi resmin ortasına yerleştirilmiştir. Şekil- 15 'de görüldüğü üzere evde yer alan ikinci resimde ise Galata Köprüsü resmedilmiştir. Resmin ön planında yerleştirilmiş olan ağaçlar, resimden ayrı dekoratif bir öğe gibi tasarlanmıştır. Resmin iki yanında iki büyük kara parçası üzerinde yoğun bir konut dokusu görülmektedir (Gürçağlar, 2005: 158). Uçar eserinde (2013: 673) benzer şekilde İstanbul temalı duvar resimleri örneklerinin Arnavutluğun Kruje, Berat, Tiran ve Korçe şehirlerindeki çeşitli konak ve cami yapılarında da görüldüğünü; 
Sultan Ahmed Camii, Ayasofya Camii, Sarayburnu ve Topkapı Sarayı, Galata Kulesi imgeleri ile İstanbul'un tasvir edildiğini belirtmektedir.

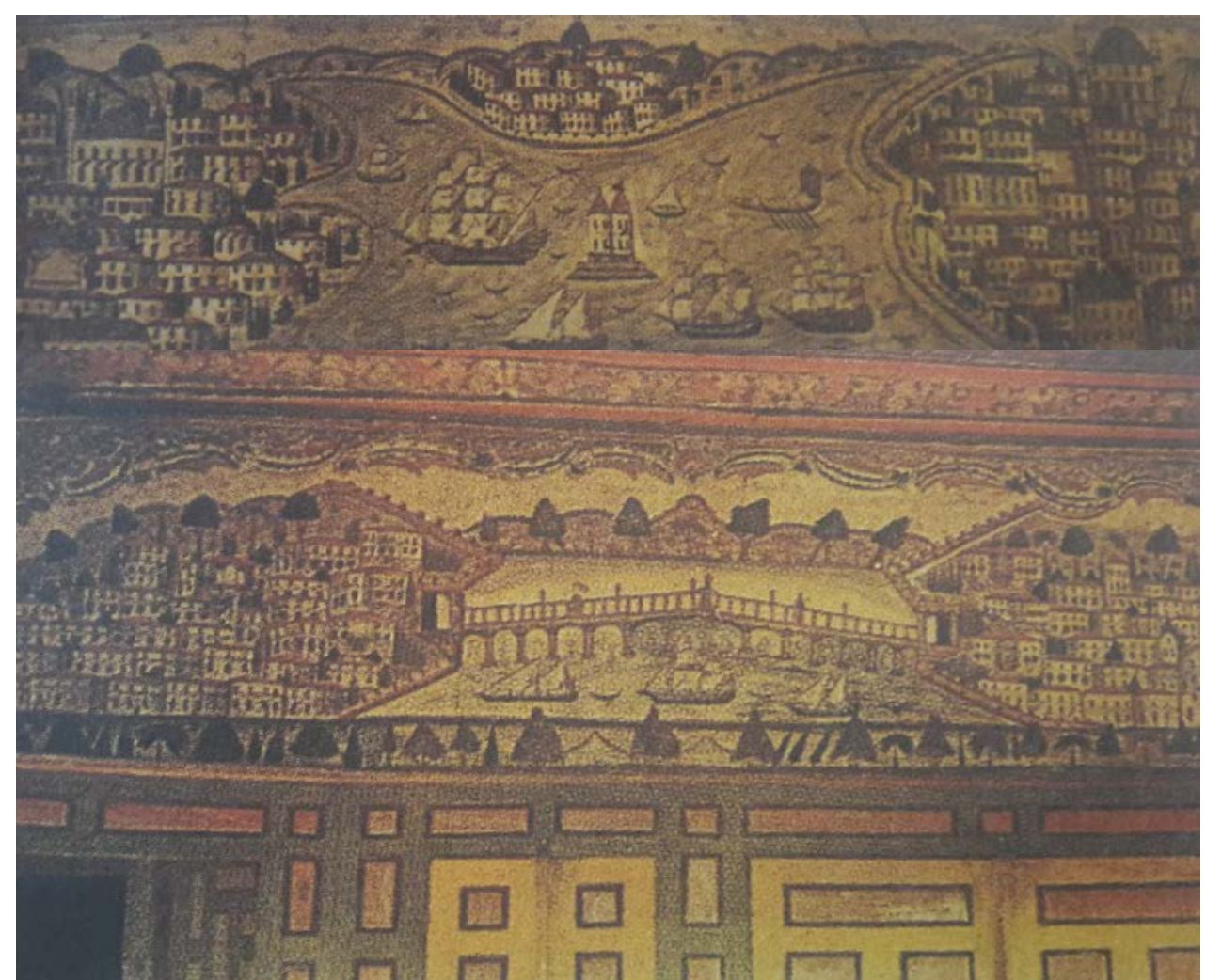

Şekil 15. Ambelakia'da Effthymiadis evinde yer alan resim (Gürçağlar, 2005:241-242).

Anadolu'da konut yapıları dışındaki mimari yapıların bazılarında da İstanbul temalı kalem işleri görülmektedir. Amasya Sultan II. Bayezid Külliyesi şadırvanının kubbesi ile Merzifon Karamustafa Paşa Camisi şadırvanı kubbesinde yer alan İstanbul temalı duvar resmi ünlü nakkaş Emin Zileli imzasını taşıdığından önem arz etmektedir. Bu nedenle çalışmada bu örneklere de yer verilmiştir. Şekil-16'da görüldüğü üzere Amasya'da bulunan Sultan II. Bayezid Külliyesi şadırvanında yer alan resim kubbenin eteğinde dar bir şerit halinde yapılmıştır. Resim kompozisyonunda üzerinde Türk bayrağı bulunan Bayezid Kulesi ve çevresinde yapılaşan İstanbul evleri yer almaktadır (Arık, 1975: 13). 


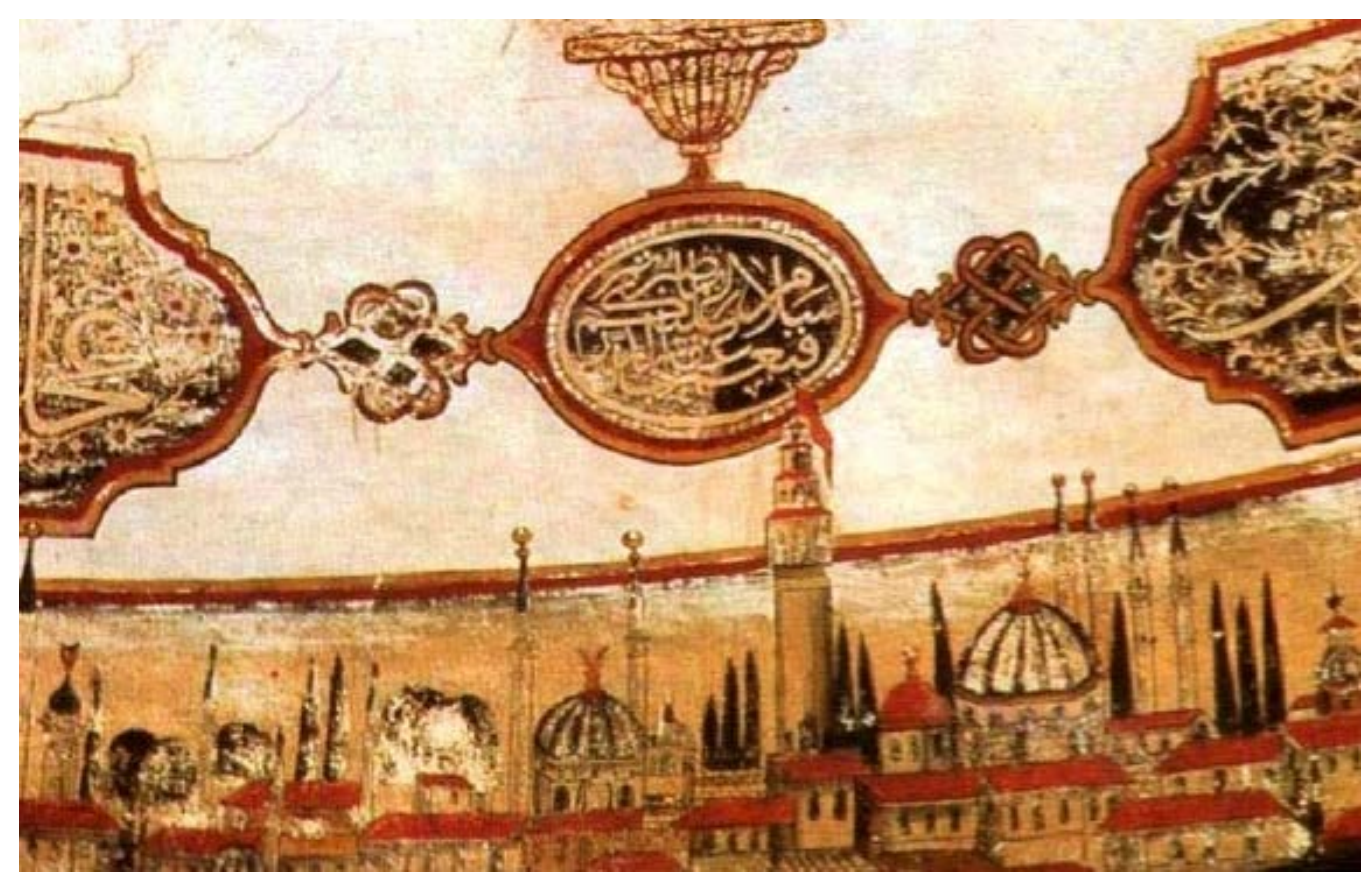

Şekil 16. Amasya II. Bayezid Külliyesi şadırvanının kubbesinde yer alan nakkaş Emin Zileli imzalı resim (Arık, 1975: 12).

Merzifon Karamustafa Paşa Camisi şadırvanında ise yarım küre biçimindeki yüzeyde resimler, tepedeki bitkisel motifli göbek kompozisyonu ile etekteki yazı bordürü arasında, alt alta dolaşan iki kuşak halinde düzenlenmiştir. 1875 tarihli resimde İstanbul manzarası Galata ve tarihi yarımadayı betimlemektedir (Arık, 1975: 9). Süleymaniye Camii, Galata Kulesi, iki cami, Haliç Köprüsü minyatür tekniğinde olduğu gibi hem kuşbakışı hem de yan yana resmedilmiştir. Ayrıca bu resimde 19. yüzyılda Almanlar tarafından Osmanlı topraklarına kazandırılan önemli bir ulaşım şekli olan demiryolunu temsil eden üç vagonlu bir tren ile buharlı birkaç gemi resmedilmiştir. Bu resim kompozisyon ve perspektif kaygısı güdülmeden temeli minyatür resmine dayalı bir İstanbul panoramasıdır (Gürçağlar, 2005: 245-246). Şekil- 17'de görüldüğü üzere resmin solunda yer alan Bayezid kulesi tepesinde Türk bayrağı ile arka planda göğe doğru yükselmektedir. Resmin sağında yer alan dikili taş ise İstanbul'da yer alan dikilitaşlardan birini tasvir etmektedir. Tek bir bütün izlenimi vererek kubbeyi kaplayan bu İstanbul panoraması aslında başlı başına bir tablo niteliğindeyken, çerçeve içine alınmamış; birbirinden ayrı resimlerin aynı üslup ve yöntemle çerçevesiz olarak birbirine bağlanmasından ortaya çıkmıştır. Bu resmin önemli bir özelliği de resim içinde yer alan ve çizilmiş bulunan imgelerin neyi simgelediğini belirten yazılardır.
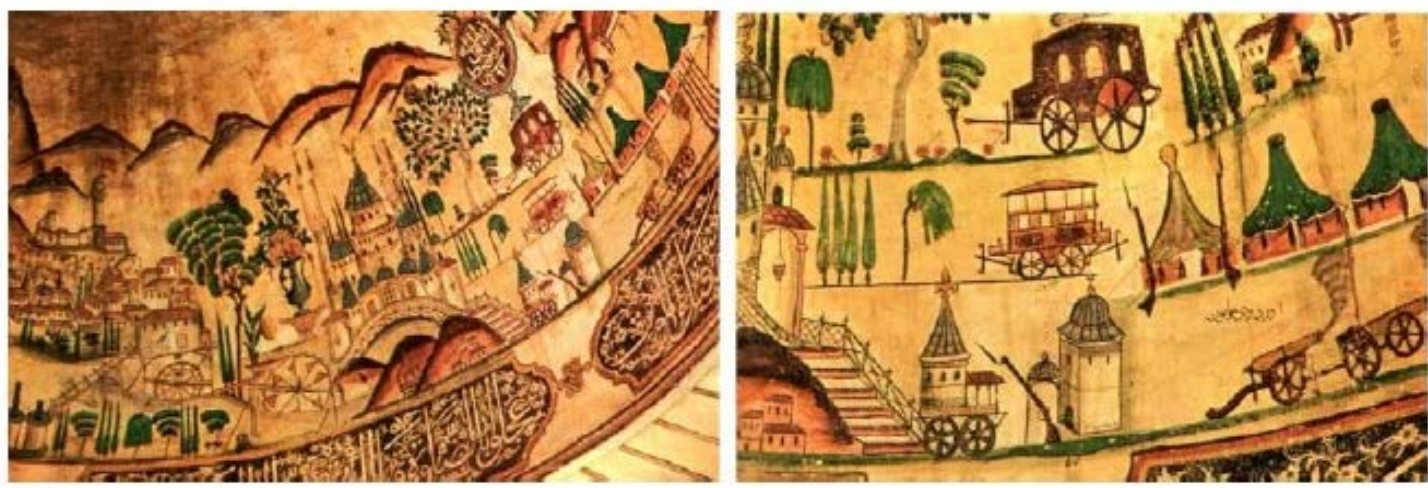

Şekil 17. Solda Merzifon Karamustafa Paşa Camisi şadırvanında yer alan İstanbul konulu duvar resmi. Sağda bu duvar resminden bir detay görülmektedir (Arık, 1975: 11). 


\section{Sonuç}

$\mathrm{Bu}$ örnekler sayıca artabilir, ancak incelenen örneklerde de görüldüğü üzere, Batılılaşma sürecinde başlayan duvar resmi uygulamalarında İstanbul temalı örneklerin tümünde belirli ortak özellikler dikkati çekmektedir. Mimaride ve doğanın betimlenişindeki boyutluluk ve doğala yakın renk tonlamalarıyla yumuşak geçişler resimlerin temel özelliğidir. İstanbul'daki örnekler gerçekçi bir anlayış taşımakta iken; İmparatorluğun diğer kentlerindeki örneklerde daha naif bir tutum gözlenmektedir. İstanbul'daki örneklerde Batılı anlamda perspektif anlayışı görülürken, İstanbul dışındaki örneklerde minyatür anlayışının halen devam etmekte olduğu görülmektedir. Öte yandan, bu resimler dönemin İstanbul'da bulunan önemli yapılarını resmettiğinden birer görsel belge olma açısından önemlilik arz ederler. Bu resimlerin yapılabilmesi amacıyla İstanbul dışındaki sanatkârlar İstanbul'u görmeye gelmişler ya da İstanbul'u gören kişilerden, çeşitli belgelerden bilgi edinmeye çalışmışlardır. Dolayısıyla bu resimler insanlar, sanat disiplinleri ve olaylar arası dolaylı ya da direk iletişimin bir ürünüdür.

Sonuç olarak; Osmanlı'da Batılılaşma etkisiyle gelişerek yeni bir boyut kazanan duvar resimleri sadece mimariye bağlı dekoratif özellikli süslemeler değildir. Çoğunluğu İstanbul konulu bu resimlerin gelişim süreci içinde Batılılaşma hareketinin bir yansıması olduğundan hem sanatsal ve estetik hem de sosyo-kültürel açıdan özellikleri bulunmaktadır.

Bu resimler sanatsal açıdan ele alındıklarında;

Batı tarzı resim sanatı özelliklerinin ilk kez uygulandığı örnekler olmaları açısından önemlidir. Bu resimler Osmanlı resim sanatında Doğu betimleme mantığının ve minyatür sanatı özelliklerinin bir kenara bırakılarak Batı sanatı çerçevesinde biçimlenmesiyle meydana gelmiştir. Türk resim sanatının imge, perspektif, renk, ışıkgölge ve mimesis gibi konularda gelişmesi açısından önemli örnekler teşkil etmişlerdir. Diğer geleneksel süsleme tekniklerine oranla daha ucuz ve Batı tarzı yeniliklere daha uygun bir teknik oluşu nedeniyle yaygın bir şekilde uygulanmışlardır. Bu resimler çoğunlukla gravür, fotoğraf, kitap gibi eserlerden edinilen bilgilere dayanılarak yapıldığından bu sanatların gelişimine paralel bir gelişim göstermişlerdir. Batı tarzı duvar resmi uygulaması saraydan başlayarak konutlarda da Batı tarzı mobilya kullanımını ve Batı tarzı dekorasyonu geliştirmiş, böylece Türk sivil mimarisinin iç mekânları estetik yönden yeni bir boyut kazanmıştır.

Bu resimler sosyo-ekonomik açıdan ele alındıklarında;

Türk sivil mimarisi, iç mekân yaşamı açısından bu resimler sayesinde Batılı bir görünüm alma yolunda ilerlemiştir. Günlük yaşam tarzı ve eşya kullanım alışkanlıkları açısından toplumda bir sınıf farkı olmayan Osmanlı İmparatorluğu'nda bu duvar resimleri mekânların sosyo-kültürel açıdan farklılığının birer belirteci olmuştur. İstanbul temalı bu duvar resimleri konut sahiplerinin Batılılaşmaya uyum gösterdiklerinin belirleyicisi öğeler olarak konut dekorasyonunda önemli bir rol oynamıştır. İmparatorluğun başkenti olan İstanbul'un sadece Anadolu ve Rumeli'de değil Avrupa'da da kültürel açıdan tanınmasında etkili bir rol oynamışlardır. Bu resimler Osmanlı resim sanatını Batıya açarken, Batı resim sanatı ile birlikte dekorasyonu Doğuya açılmıştır. Özellikle Avrupa ülkeleri İstanbul'u konu alan süslemeleri ile Osmanlı pazarına sunmak üzere eşya üretmeye başladığından konu ticari bir boyut da kazanmıştır.

Osmanlı'nın Avrupa tarafından tanınmasında, Avrupa kültürünün ve sanatının Osmanlı toplumuna tanıştırımasında resim sanatı önemli bir araç olmuştur. Doğu ile Batı uygarlıkları arasında bir iletişim köprüsünün kurulmasında resim sanatı bir öncü olmuş, 
özellikle mimarinin bir parçası olarak uygulanan duvar resmi tekniği vasıtayla mimari mekân ve dekorasyon bu iletişimin kurulmasında bir köprü vazifesi görmüştür. Bu resimlerde İstanbul şehrinin ele alınmasındaki temel nedenler ise İstanbul'un Batılılaşan Osmanlı'nın Avrupa'ya açılan kapısı olmasından dolayı tüm Osmanlı halkının yaşamayı ümit ettiği bir şehir oluşu ve Batılıların dahi yaşamayı hayal ettikleri bu şehri gravür, tablo, kitaplar, çeşitli eşyalar gibi eserlerde betimleyerek bunların Osmanlı halkı tarafından ilgi görmesi gelmektedir. Özetle İstanbul konulu duvar resimleri Türk resim sanatında nakkaştan ressama geçiş sürecinin yaşandığı, İstanbul kentinin ve dolayısıyla da tüm Osmanlı toplumunun geleneksel yaşamdan Batı tarzı yaşama yönelişte katı kuralların çiğnenerek adım atıldığı somut örnekler olması açısından önem taşımaktadır.

\section{KAYNAKÇA}

AKIN, N. (2001). Balkanlarda Osmanlı Dönemi Konutları. İstanbul: Literatür Yayıncılık.

AKŞiT, İ. (2005). The Topkapı Palace. İstanbul: Akşit Yayıncılık.

ARIK, R. (1975). “Anadolu'da Bir Halk Ressamı", Türkiyemiz Dergisi. no.16, s: 9-13.

ARLI DEMIRSAR, B.(2000). Oryantalizmden Çağdaş Türk Resmine. İstanbul: Creative Yayınları.

BATUR A. (2005). Rural Architecture in the Eastern Black Sea Region. İstanbul: Milli Reasürans Yayınları.

CEZAR, M. (1995). Sanatta Batı'ya Açılış ve Osman Hamdi. İstanbul: Ekav Vakfı Yayınları.

ÇALIŞıR, D. (2008). "Osmanlı Görsel Kültüründe Meyve Teması: Geleneksel Natürmort Resimleri Bağlamında Bir Değerlendirme", Turkish Studies International Periodical for the Languages, Literature and History of Turkish or Turkic. Volume 3/5 Fall 2008, p. 65-86. ISSN: 1308-2140, www.turkishstudies.net, Doi Number: http://dx.doi.org/10.7827/TurkishStudies.410.

ÇELIK, E., ERSOY, İ., K. (2016). "Kocaeli Yapılarında Bulunan Resimli Bezemelerden Örnekler", Gazi Akçakoca Sempozyumu Bildiri Kitabı, s: 1651-1665.

DEMIRARSLAN, D. (2007). "Modernisation and Changing House Design in Turkey: From the 19th Century to the Present", Regional Architecture and Identity, in the Age of the Globalization CSAAR, Editörler: Jamal Al- Qawasmi, Abdesselem Mahmoud, Ali Djerbi, CSAAR Yayınevi, s:603-617.

DEMiRARSLAN, D. (2011) "Eski Bir Bektaşi Yerleşimi: Yörük Köyü'nde Evler ve Odanın Oluşumu", Türk Kültürü Ve Haci Bektaş Veli Araştirma Dergisi.s: 69-88.

DíLMAÇ, O. (2012). "Avrupa'da Eğitim Gören Sanatçılarımızın Çağdaş Türk Sanatının Gelişimindeki Rolü”, Inönü Üniversitesi Sanat ve Tasarım Dergisi. 4(2012):85-101.

ELİRi, İ. (2010). "Batılılaşma Sürecinde askeri Okullar ve Asker Ressamların Türk Resim Sanatına Etkileri”, Türk İslam Medeniyeti Akademik Araştırmalar Dergisi. 9(2010):139-150.

GÜLTEKIN R. (2008). "Türklerde Bereket Sembolü Olarak Kullanılan Meyve Motifleri ve Mimaride Değerlendirilmesi", Turkish Studies International Periodical for the 
Languages, Literature and History of Turkish or Turkic. Volume 3/5 Fall 2008, p.9-31. ISSN: 1308-2140, www.turkishstudies.net, Doi Number: http://dx.doi.org/10.7827/Turkish Studies.408.

GÜRÇAĞLAR, A. (2005). Hayali İstanbul Manzaraları. İstanbul: Yapı Kredi Yayınları.

KUBAN, D.(2007). Osmanlı Mimarisi. İstanbul: Yapı Endüstri Merkezi Yayınları.

KUŞOĞLU, M. Z., (2010). Osmanlı Medeniyetinde 33 Kadim Sanat. İstanbul: Kaynak Kültür Yayınları.

ÖNDiN, N., (2000). "Türk Manzara Resmi", Muğla Üniversitesi SBE Dergisi 1., no.2 (2000), http://www.mu.edu.tr/sbe/sbedergi/dosya/2_14/pdf (Erişim tarihi: 5 Ekim 2009).

ÖNER, S. (1992). Tanzimat Sonrası Osmanlı Saray Çevresinde Resim Sanatı. İstanbul: Milli Saraylar Yayını.

RENDA, G.(1997). Batıılaşma Döneminde Türk Resim Sanatı 1700-1850. Ankara: Hacettepe Üniversitesi Yayınları.

RENDA, G. (1985). "19. Yüzyılda Kalem işi, Nakış ve Duvar Resmi”, Tanzimat'tan Cumhuriyete Türkiye Ansiklopedisi, Ankara: İletişim Yayınları.

Antique Decorative Objects, İstanbul: de Péra müzayede Evi yayını, 2003.

TEKINALP, P., Ş., (2006). "Duvar Resimlerinde Köşk, Kasır ve Saraylar", Uluslararası Dolmabahçe Sempozyumu Bildiriler. İstanbul, 23-26 Kasım 2006, s:114-122.

UÇAR, M. (2013). “Arnavutluk'taki Osmanlı Dönemi Mimarisinde İstanbul Tasvirli Duvar Resimleri", Turkish Studies International Periodical for the Languages, Literature and History of Turkish or Turkic. Volume 8/7 Summer 2013, p.671-686, ISSN:1308- 2140, www.turkishstudies.net, Doi Number: http://dx.doi.org/10.7827/TurkishStudies.5313.

YAŞAR, F.T. (2012). "Geç Dönem Osmanlı Âdâb-ı Muâşeret Kitaplarında Hane Tanzimi ve Salon Âdâbı", Turkish Studies International Periodical for the Languages, Literature and History of Turkish or Turkic. Volume 7/4 Fall 2012, p.2919-2938, ISSN:1308- 2140, www.turkishstudies.net, Doi Number: http://dx.doi.org/10.7827/TurkishStudies.3865.

URL-1: http://www.artnet.com/artists/jean-baptiste-hilaire/past-auction-results(Erişim tarihi: 08.09.2015)

URL-2: http://www.cornucopia.net/blog/jewel-sadberk-hanim-exhibition/ (Erişim tarihi: 04.10.2016)

URL-3: $\quad$ http://www.kulturportali.gov.tr/turkiye/genel/gezilecekyer/demirciler-konagi (Erişim tarihi: 04.10.2016)

URL-4: http://www.archilovers.com/stories/579/the-decorative-painting-in-the-manorhouse-of-georgios-schwarz-in-ampelakia-thessaly-greece.html (Erişim tarihi: 04.10.2016) 